Harmful Algae

December 2014, Volume 40 Pages 75-91

http://dx.doi.org/10.1016/i.hal.2014.10.006

http://archimer.ifremer.fr/doc/00225/33611/

(C) 2014 Elsevier B.V. All rights reserved.

\title{
Genetic diversity of the harmful family Kareniaceae (Gymnodiniales, Dinophyceae) in France, with the description of Karlodinium gentienii sp. nov.: A new potentially toxic dinoflagellate
}

\author{
Nézan Elisabeth ${ }^{1,{ }^{*}}$, Siano Raffaele ${ }^{2}$, Boulben Sylviane ${ }^{1}$, Six Christophe ${ }^{3,4}$, Bilien Gwenael ${ }^{1}$, \\ Cheze Karine ${ }^{5}$, Duval Audrey ${ }^{1}$, Le Panse Sophie ${ }^{6}$, Quéré Julien ${ }^{2}$, Chomérat Nicolas ${ }^{1}$
}

\footnotetext{
${ }^{1}$ IFREMER, Station de Biologie Marine, Place de la Croix, BP 40537, F-29185 Concarneau Cedex, France

2 IFREMER, Centre de Bretagne, DYNECO/Pelagos, BP 70, F-29280 Plouzané, France

${ }^{3}$ Sorbonne Universities, Pierre et Marie Curie University (Paris 06), UMR 7144, Marine Phototrophic Prokaryotes Group, Station Biologique de Roscoff, 29688 Roscoff Cedex, France

${ }^{4}$ Centre National pour la Recherche Scientifique, UMR 7144, Marine Phototrophic Prokaryotes Group, Station Biologique de Roscoff, Place Georges Teissier, CS90074, 29688 Roscoff Cedex, France

${ }^{5}$ Muséum National d'Histoire Naturelle, Station de Biologie Marine, BP 225, F-29182 Concarneau Cedex, France

${ }^{6}$ Centre National pour la Recherche Scientifique, Fr 2424, Plate-forme Merimagerie, Station Biologique de Roscoff, Place Georges Teissier, CS90074, 29688 Roscoff Cedex, France
}

* Corresponding author: Elisabeth Nézan, tel.: +33 298104280 ; fax: +33 298104281 ; email address : elisabeth.nezan@ifremer.fr

\begin{abstract}
:
The family Kareniaceae is mostly known in France for recurrent blooms of Karenia mikimotoi in the Atlantic, English Channel, and Mediterranean Sea and for the unusual green discoloration in the saltwater lagoon of Diana (Corsica) caused by Karlodinium corsicum in April 1994. In terms of diversity, this taxonomic group was long overlooked owing to the difficult identification of these small unarmored dinoflagellates. In this study, thanks to the molecular characterization performed on single cells from field samples and cultures, twelve taxonomic units were assigned to the known genera Karenia, Karlodinium and Takayama, whereas one could not be affiliated to any described genus. The molecular phylogeny inferred from the D1-D2 region of the LSU rDNA showed that five of them formed a sister taxon of a known species, and could not be identified at species-level, on the basis of molecular analysis only. Among these latter taxa, one Karlodinium which was successfully cultured was investigated by studying the external morphological features (using two procedures for cells fixation),
\end{abstract}


ultrastructure, pigment composition, and haemolytic activity. The results of our analyses corroborate the genetic results in favour of the erection of Karlodinium gentienii sp. nov., which possesses an internal complex system of trichocysts connected to external micro-processes particularly abundant in the epicone, and a peculiar pigment composition. In addition, preliminary assays showed a haemolytic activity.

\section{Highlights}

The diversity of the Kareniaceae in France was genetically studied. A taxon from the Atlantic clustered with a Dinophyceae from Antarctica in a new clade. Karenia brevisulcata and K. umbella were unexpectedly detected. The new potentially toxic dinoflagellate Karlodinium gentienii was described. $-K$. gentienii showed a complex trichocyst system and a peculiar pigment composition.

\section{Abbreviations}

- $\quad$ LBS, ML bootstrap support;

- BPP, Bayesian posterior probabilities

Keywords : Genetic diversity, Haemolytic, Kareniaceae, Pigments, Single cell, Taxonomy 


\section{Introduction}

The family Kareniaceae of the order Gymnodiniales has been erected to encompass unarmored dinoflagellates whose chloroplasts contain fucoxanthin and/or fucoxanthinderivatives, and which possess a straight or sigmoid apical groove (Bergholtz et al., 2005). It includes the genera Karenia G. Hansen et Moestrup, Karlodinium J. Larsen and Takayama de Salas, Bolch, Botes et Hallegraeff, to which several unarmored dinoflagellates previously classified under the large genera Gymnodinium Stein and Gyrodinium Kofoid et Swezy are affiliated (Daugbjerg et al., 2000; de Salas et al., 2003). Mortality and ichthyotoxicity phenomena have been described worldwide for a long time, associated to recurrent blooms of Karenia brevis (Davis) G. Hansen et Moestrup in North America (Landsberg and Steidinger, 1998), Karenia mikimotoi (Miyake et Kominami ex Oda) G. Hansen et Moestrup in Japan, Europe, Australia and New Zealand (Takayama and Adachi, 1984; Dahl and Tangen, 1993; Hallegraeff, 2002), K. selliformis Haywood, Steidinger et MacKenzie in Tunisia and Chile (Clément et al., 2001; Medhioub et al., 2009), Karlodinium veneficum (Ballantine) J. Larsen in North America, Australia and Europe (Deeds et al., 2002; Kempton et al., 2002; Garcés et al., 2006; Hallegraeff et al., 2010; Place et al., 2012). Finally, an extremely toxic bloom of Karenia brevisulcata devastated all marine life in 1998 in New Zealand (Chang, 1999).

In France, the Kareniaceae family is mostly known for recurrent blooms of K. mikimotoi (previously recorded as Gyrodinium cf. aureolum or Gymnodinium cf. nagasakiense) which occur from the Atlantic to the English Channel (Partensky et al., 1991). Several works have been achieved in these areas in order to better understand the bloom dynamics of this species and subsequently build up mathematical models of this species (Morin et al., 1989; Gentien et al., 1997; Loyer et al., 2001; Vanhoutte-Brunier et al., 2008). The two most significant bloom events occurred in 1995 along the whole French Atlantic coast (Arzul et al., 1995) and in 2003 off the Western English Channel (Vanhoutte-Brunier et al., 2008). Massive mortality of marine fauna, including fish (wild and reared), sea urchins (Echinocardium cordatum), lugworms (Arenicola marina) and many bivalves was associated to the previous event (Arzul et al., 1995). The second one was intense and extended enough to be visible by remote sensing satellite of surface seawater color (Vanhoutte-Brunier et al., 2008). At a smaller scale, the Mediterranean coast and especially some lagoons, can also be affected by blooms of Karenia mikimotoi. In the Corsican lagoon of Diana, mortality of sea bass and sea bream, reared in cages, has already been reported (Bodennec et al., 1994). In 1994, in this same lagoon, another species first identified as Gyrodinium corsicum (Paulmier et al., 1995) and later transferred to the genus Karlodinium on the basis of its morphological similarities with other Karlodinium species (Siano et al., 2009), was responsible for a green discoloration of water. Farmed fish mortality was also observed but the toxicity of this dinoflagellate had not been demonstrated (Paulmier et al., 1995). Since that date, no bloom was recorded and the toxicity of this species could not be reconsidered. A third species, Karenia papilionacea Haywood et Steidinger (first identified as Gymnodinium cf. breve), has been observed in low abundance since 1994 especially in Western Brittany on the Atlantic coast (Nézan, 1998; Haywood et al., 2004). In the early 2000s, a study of the genetic diversity of the genus Karenia along the French coasts was achieved but did not reveal any other species than those previously identified (Guillou et al., 2002).

In 2008, massive losses of juvenile oysters along the French coasts brought back the attention towards the family Kareniaceae. A number of 58 water samples were collected in several production areas of oysters. Although this family was present in 39 samples, no bloom was observed and cultures which could have allowed the analysis 
of the harmfulness of Kareniaceae were not established. Over a period of two years (2012-2013), single cells of Kareniaceae were isolated from live material sampled on both Atlantic (Brittany) and Mediterranean (Corsica) coasts in order to start cultures and evaluate their potential toxicity. Several strains were thus obtained, including a novel Karlodinium species. In this paper, we first analyze all data (partial rDNA sequences and images acquired from single cells and cultures) collected on Kareniaceae in France in order to contribute to the knowledge of the diversity and global biogeography of this family. Then, on the basis of one cultivated strain, we propose the description of a new species, Karlodinium gentienii sp. nov., using light and electron microscopy, molecular phylogeny, pigment composition and haemolytic activity.

\section{Material and methods}

\subsection{Specimen collection and cultivation.}

For specimen collection, a number of 19 near surface seawater samples collected between 2007 and 2013 in ten sites ( 5 from the Atlantic and 5 from Mediterranean Sea) by the IFREMER national monitoring network (REPHY) were selected for this study, based on the presence of Kareniaceae. They were either living or preserved with acidic Lugol's lodine solution ( $0.1 \%$ final concentration) and stored at $4{ }^{\circ} \mathrm{C}$ until examination.

For cultivation, single cells were isolated from live samples by micropipeting under an IMT2 inverted light microscope (Olympus, Tokyo, Japan) and placed on 96 well plates filled with $0.2 \mathrm{~mL}$ of $\mathrm{K} / 2$ medium (Keller et al., 1987). The plates were incubated at 16 ${ }^{\circ} \mathrm{C}$ under 80-100 $\mathrm{mmol}$ photons $\mathrm{m}^{-2} \mathrm{~s}^{-1}$ in a 12:12 light:dark photocycle. After some cell divisions, the clonal strains were transferred to plates with progressively increasing well volumes. Using this procedure, a clonal culture of Karlodinium gentienii sp. nov. was obtained. The strain was maintained in $50 \mathrm{~mL}$ culture flasks and cultivated in the conditions described above. The corresponding seawater sample was collected in Concarneau Bay $\left(47^{\circ} 50.091^{\prime} \mathrm{N}, 3^{\circ} 57.0369^{\prime} \mathrm{W}\right)$ in July 2012 when surface water temperature was $16.1^{\circ} \mathrm{C}$ and salinity 34.9.

\subsection{Light microscopy (LM)}

For the study of the genetic diversity of Kareniaceae, the observations of seawater samples were carried out using an Olympus IX70 inverted light microscope equipped with differential interference optics and a digital camera DP72 (Olympus, Tokyo, Japan). For the description of Karlodinium gentienii sp. nov., live cultivated cells were examined under a BX41 (Olympus, Tokyo, Japan) upright microscope equipped with both differential interference optics, an Osram mercury short arc HBO 100W lamp as light source for epifluorescence, and filtersets U-MWU2 for DAPI stain (excitation: BP330-385; beamsplitter: DM400; and emission: BA420) and U-MWIB2 for chlorophyll autofluorescence (excitation: BP460-490; beamsplitter: DM505; and emission: BA510IF). This equipment allowed to visualize the chloroplasts directly or the nuclei after staining with 4', 6-diamidino-2-phenylindole (DAPI). Light micrographs of both fixed and living cells were obtained using a digital camera DP72 (Olympus, Tokyo, Japan). Measurements of live cultivated cells of Karlodinium gentienii in their exponential growth phase were performed on LM digital micrographs using ImageJ software (Rasband, 1997-2006). 


\subsection{Scanning electron microscopy (SEM)}

To better observe external morphological features of Karlodinium gentienii, two procedures with a different combination of fixatives were attempted. For the first method, cultivated cells were fixed with an equal volume of $4 \%$ osmium tetroxide $(2 \%$ final concentration) and $0.5 \%$ glutaraldehyde (final concentration) for $1 \mathrm{~h}$ at room temperature, before a first rinse in seawater and a second rinse in deionized water. In the second procedure, cells were fixed with $1 \%$ acidic Lugol's solution and $1 \%$ glutaraldehyde (final concentrations). Fixed cells were stored at $4{ }^{\circ} \mathrm{C}$ before dehydrating. Then, they were processed according to the methods described in Couté (2002) and Chomérat and Couté (2008). After gold-palladium coating, cells were observed with a Quanta 200 (FEI, Eindhoven, Netherlands) scanning electron microscope. SEM images are presented on a uniform background using Adobe Photoshop CS2 (V. 9.0.2, Adobe Systems, San Jose, CA, USA).

\subsection{Transmission electron microscopy (TEM)}

TEM was used for the analysis of $K$. gentienii cell ultrastructure. Samples were fixed for 5 hours in a fixative mix containing $4 \%$ glutaraldehyde, $0.2 \mathrm{M}$ sodium cacodylate buffer (pH 7.4) and, $0.25 \mathrm{M}$ sucrose. Samples were then rinsed in a series of buffer solutions containing graded concentrations of sucrose and $\mathrm{NaCl}$ (from $0.25 \mathrm{M}$ sucrose, $0.22 \mathrm{M}$ $\mathrm{NaCl}$ in $0.2 \mathrm{M}$ sodium cacodylate to $0.35 \mathrm{M} \mathrm{NaCl}$ in $0.2 \mathrm{M}$ sodium cacodylate) and post-fixed for 1 hour at $4{ }^{\circ} \mathrm{C}$ in $1 \%$ osmium tetroxide buffered in $0.2 \mathrm{M}$ of sodium cacodylate and $0.33 \mathrm{M} \mathrm{NaCl}$. After rinsing three times for $15 \min$ in $0.35 \mathrm{M} \mathrm{NaCl}$ and $0.2 \mathrm{M}$ sodium cacodylate, dehydratation was carried out in a graded alcohol series (from 30 to $100 \%$ ). Finally, samples were embedded in Epon resin. Sections were performed using diamond knifes on a ultracut UCT ultramicrotome (Leica Microsystems, Wetzlar, Germany) and after stained with $2 \%$ uranyl acetate for 10 min and $2 \%$ lead citrate for 3 min. Sections were mounted on grids and examined with a Jeol 1400 transmission electron microscope (Jeol, Tokyo, Japan).

\subsection{Genetic analyses}

Single cells were isolated from live or Lugol-fixed samples by micropipeting under an Olympus IX70 inverted light microscope, and deposited on a glass slide. They were observed at 600X magnification, photographed with an Olympus DP72 digital camera, and rinsed into several drops of double distilled water (Milli-Q water) before transfer to a $0.2 \mathrm{ml} \mathrm{PCR}$ tube containing $3 \mu \mathrm{l}$ of Milli-Q water. PCR tubes were stored at $-20^{\circ} \mathrm{C}$ until direct PCR amplifications. For PCR, tubes were thawed and processed as described in Nézan et al. (2012). The nuclear markers LSU rDNA and the internal transcribed spacer region (ITS1-5.8S rDNA-ITS2) were amplified using the primers given in Nézan et al. (2012).

Sequences were assembled using BioEdit v. 7.0.9.0 software (Hall, 1999). A total of 39 LSU rDNA sequences and two ITS region sequences were generated in our laboratory to infer the phylogeny of the Kareniaceae. The first set of sequences was aligned together with 52 LSU sequences of the order Gymnodiniales retrieved from GenBank and the second one with 12 ITS sequences, using the multiple sequence alignment program MUSCLE v. 3.7 (Edgar, 2004). Each alignment was refined by eye. The two data matrices obtained (92 LSU rDNA sequences, 830 characters and 14 ITS region sequences, 784 characters) were analyzed by two methods of phylogenetic reconstruction: maximum likelihood (ML), using PhyML v 3.0 software (Guindon and Gascuel, 2003) and Bayesian inference (BI) using MrBayes v.3.1.2 (Ronquist and Huelsenbeck, 2003). The software jModeltest v 0.1.1 (Posada, 2008) was first used to 
select the most suitable model of substitutions. The General-Time Reversible models $\left(\mathrm{GTR}+\Gamma_{8}\right)$ and $\left(\mathrm{GTR}+\mathrm{I}+\Gamma_{4}\right)$ were chosen for the LSU and ITS markers respectively, as indicated by the Hierarchical Likelihood Ratio Tests (hLRTs), Akaike Information Criterion 1 (AIC1), Akaike Information Criterion 2 (AIC2) and Bayesian Information Criterion (BIC) tests implemented in jModeltest. Bootstrap values (support for branches) of trees were obtained after 1000 iterations in ML. For Bayesian inference, four Markov chains were run simultaneously for $2 \times 10^{6}$ generations with sampling every 100 generations. On the $2 \times 10^{4}$ trees obtained, the first 2000 were discarded (burn-in) and a consensus tree was constructed from the remaining trees. The posterior probabilities corresponding to the frequency with which a node is present in preserved trees, were calculated using a coupled Monte Carlo Metropolis approach Markov Chain (MCMC).

\subsection{Pairwise distances}

The genetic pairwise distances ( $p$-distances), based on the D1-D2 region of the LSU rDNA gene were estimated using MEGA5 software (Tamura et al., 2011). Several sequences of Karenia, Karlodinium and Takayama retrieved in Genbank and acquired in this study (Table S1) were aligned using Clustal W in MEGA5. The variability between individuals of the same species was estimated by the range (minimum and maximum values) of pairwise distances retrieved from the distance matrix. To estimate the average range of distances between species within each genus, all sequences were assigned to groups (species) in MEGA5 and 'between groups means' were computed. Minimum and maximum mean values were given for each of the three genera. The taxa which were not identified at species-level were excluded from this calculation since it was not possible to assign them certainly in one group. Their average distance to the closest identified taxon was calculated to evaluate whether they were likely new undescribed species ( $p$-value $>$ average among species within a genus) or a known species with slightly divergent sequences ( $p$-value $<$ average among individuals within a species).

\subsection{Pigment analyses.}

Volumes of $30 \mathrm{~mL}$ of culture of Karlodinium gentienii in exponential phase were supplemented with pluronic acid, pelleted by centrifugation at $8,000 \times g$, and the pellets were then frozen and stored at $-80{ }^{\circ} \mathrm{C}$ until further analysis. The pellets were resuspended in $500 \mu \mathrm{L} 100 \%$ cold methanol and stored at $-20{ }^{\circ} \mathrm{C}$ for 1 hour. Karlodinium pigments were easy to extract as the cells immediately and completely collapsed in methanol. The suspension was then centrifuged at 20,000 $\times g$ to ensure the removal of all particles and cell debris. The supernatant was then brought to $10 \%$ Milli-Q water to avoid peak distortion (Zapata and Garrido, 1991) and a volume of 100 $\mu \mathrm{L}$ of the pigment extract was immediately injected into an HPLC Hewlett-Packard HPLC 1100 Series system, equipped with a quaternary pump and diode array detector. Pigment separations were performed using a Waters Symmetry $\mathrm{C}_{8}$ column $(150 \times 3 \times$ $4.6 \mathrm{~mm}, 3.5 \mu \mathrm{m}$ particle size) according to procedures published elsewhere (Zapata et al., 2000; Six et al., 2005) at a flow rate of $1 \mathrm{~mL} \mathrm{~min}^{-1}$. All sample preparations were made under subdued light. Chlorophylls and carotenoids were detected by their absorbance at $440 \mathrm{~nm}$ and identified by diode array spectroscopy. Pigments were identified and quantified using standards derived from macroalgae and phytoplankton cultures by preparative HPLC (Repeta and Bjørnland, 1997), using previously compiled extinction coefficients (Roy et al., 2011). For comparison, the strain RCC2539 of $K$. veneficum was analyzed in the same conditions. 


\subsection{Haemolytic assay}

Haemolytic activity of the culture of Karlodinium gentienii was assessed using the procedure described by Arzul et al. (1994) and modified by Eschbach et al. (2001). Horse blood obtained from Labocéan (Quimper, France) was used and the erythrocyte solution prepared according to Arzul et al. (1994).

Cells concentrations in the culture of $K$. gentienii in stationary phase were estimated with a Fuchs-Rosenthal counting chamber under a BX41 upright microscope. As the concentrations were not high enough to perform the tests in triplicate, a volume of the culture was centrifuged at $8,00 \times g$ for 15 min to concentrate cells in a pellet. The supernatant was discarded and the pellet containing a known number of algal cells was resuspended in $13.5 \mathrm{~mL}$ of $\mathrm{NaCl}(0.16 \mathrm{M})$ so that three tubes containing $4.5 \mathrm{~mL}$ of the algal solution and $500 \mu \mathrm{L}$ of the erythrocyte solution $\left(50 \times 10^{6}\right.$ cells $\left.\mathrm{L}^{-1}\right)$ could be prepared. Hence, two algal concentrations $\left(20 \times 10^{3}\right.$ cells mL $\mathrm{m}^{-1}$ and $70 \times 10^{3}$ cells $\left.\mathrm{mL}^{-1}\right)$ were tested in triplicate. For comparison, three tubes with a concentration of $20 \times 10^{3}$ cells $\mathrm{mL}^{-1}$ of Karlodinium armiger (strain IFR-KAR-01D) were prepared in the same way. To measure the natural haemolysis of erythrocytes occurring without addition of any haemolytic substance, $500 \mu \mathrm{L}$ of the erythrocyte solution were added to $4.5 \mathrm{~mL}$ of $\mathrm{NaCl}$ solution at $0.16 \mathrm{M}$. In contrast, to induce $100 \%$ haemolysis (control) by osmotic stress, $500 \mu \mathrm{L}$ of the erythrocyte solution were added to $4.5 \mathrm{~mL}$ of distilled water. A standard curve with increasing concentrations of erythrocytes was prepared according to Eschbach et al. (2001) in order to relate the absorbance with the percentage of haemolysis. The suspensions were incubated in the dark at room temperature for 90 min. After incubation, samples were centrifuged $10 \mathrm{~min}$ at $8,00 \times g$ to pellet the intact erythrocytes. The absorbance of the supernatant was measured at $414 \mathrm{~nm}$ with a UV1650PC spectrophotometer (Shimadzu, Kyoto).

\section{Results}

\subsection{Genetic diversity of Kareniaceae}

Molecular analyses of LSU rDNA sequences of individual cells allowed to assign 12 taxonomic units to the known genera Karenia, Karlodinium and Takayama, whereas one taxon could not be affiliated to any described genus and thus was classified at the family-rank. (Fig. 1 and Table 1). Our ML topology of the LSU (D1-D2 region) is coherent with those previously described (de Salas et al., 2008; Siano et al., 2009) except for a new independent clade formed by the identical sequences of two specimens of the unidentified Kareniaceae. (Fig. 10-P). This clade is basal to the clades of the genera Takayama and Karlodinium, and separates from the clade corresponding to the genus Karenia (Fig. 2). The ML tree inferred from an ITS region (ITS1-5.8S rDNA-ITS2) data matrix confirms the position of this clade with a wellsupported node (90 LBS, 1.00 BPP), and including not only our taxon entitled Kareniaceae sp. but also the Dinophyceae sp. from Ross Sea for which ITS sequences were available unlike LSU sequences (Figs. $1 \mathrm{~N}$ and 3).

Among the twelve taxonomic units assigned to a known genus, seven of them referred to Karenia brevisulcata, K. mikimotoi, K. papilionacea, K. umbella, Karlodinium armiger, $K$. decipiens and $K$. veneficum, based on a $100 \%$ similarity with reference sequences. The five others formed a sister taxon of a known species, and their sequences were distant from sequences of the type locality. So, they could not be identified at specieslevel on the basis of molecular analysis only. The genetic distances were estimated showing that the variability among species within a genus ranged from $2.9 \%$ to $9.0 \%$ in Karenia, from $2.0 \%$ to $9.9 \%$ in Karlodinium, and from $1.1 \%$ to $4.0 \%$ in Takayama 
(Table 2). The variability among individuals (strains) of the same species ranged from 0 $\%$ to $1.6 \%$ for Karenia species, from $0 \%$ to $1.5 \%$ for Karlodinium species, and was null for Takayama species, except for $T$. acrotrocha (Table 2). A first unidentified taxon of the genus Karenia, named K. sp1, and originating from the Atlantic Ocean was a sister taxon to $K$. papilionacea in the ML tree inferred from LSU rDNA (D1-D2) sequences with a well-supported node (87 LBS, $1.00 \mathrm{BPP}$ ) while the average distance between these two taxa was $2.9 \%$ (Fig. 2 and Table 2). A second taxon of the same genus, named Karenia sp2, and originating from Mediterranean Sea or Corsica coast clustered with $K$. umbella with a high support (97 LBS, 0.99 BPP) while the $p$-distance between these two taxa was $1.2 \%$. For the genus Karlodinium, two sequences of one unidentified taxon from the Atlantic and Mediterranean Sea formed a sister clade to the reference sequence of $K$. corrugatum from Southern Ocean with a high support (96 LBS, 1.00 BPP), while the distance between the two taxa was $2.7 \%$. This corresponding taxon was designated Karlodinium sp. Another taxon of the same genus and originating from the Atlantic clustered with $K$. ballantinum and was erected as a new species (see description below). For the genus Takayama, two sequences originating from the Atlantic and classified as Takayama sp. diverged from $0.4 \%$ with the closest related sequences of $T$. tasmanica from Australia (type locality), New Zealand and China Sea. (Table 2).

\subsection{Characterization of Karlodinium gentienii}

\subsubsection{Karlodinium gentienii Nézan, Chomérat et Siano sp. nov. (Figs. 4-8)}

Diagnosis: unarmored and small cells, ovoid in shape, 13.5-18.9 $\mu \mathrm{m}$ long and 11.5$16.8 \mu \mathrm{m}$ wide, and almost circular in transverse section. Epicone conical with parallel and twisted furrows underlied by rows of micro-processes. Hypocone hemispherical. Cingulum displaced $25-31 \%$ of the cell length. Sulcus extending onto the epicone, and with an intercingular tubular structure. Apical groove or carina linear to slightly curved with thick margins, and extending briefly onto the dorsal epicone. Ventral pore present. Nucleus large, primarily central and irregular in shape. Several elongated chloroplasts (5-7) at the cell periphery, and containing conical pyrenoids. Amphiesmal plug-like structures not detected. A conspicuous trichocyst system connected to external microprocesses.

Holotype: SEM stub IFR-13J7, prepared from strain IFR-KGE-01C, fixed to display the amphiesmal vesicles, deposited at the Centre of Excellence for Dinophytes Taxonomy (CEDiT) with the accession reference CEDiT2014H38. Fig. 6A-G.

Isotypes: cells from a formalin fixed sample (strain IFR-KGE-01C) deposited at the CEDIT (designation CEDiT2014I39).

Etymology: the species is named to honour Dr. Patrick Gentien, our dear missing colleague and collaborator who was deeply involved in international cooperation on harmful algae bloom research. His contribution in the ecology and oceanography of Karenia mikimotoi was fundamental (Reguera and Smayda, 2012). This new Karlodinium species has been detected for the first time in 2010 in Brest Bay where Patrick spent many years of his professional career.

Type locality: Concarneau Bay $\left(47^{\circ} 50.091^{\prime} \mathrm{N}, 3^{\circ} 57.0369^{\prime} \mathrm{W}\right)$.

Distribution: presently known from the Atlantic coast of Brittany. 
Habitat and ecology: every time the organism has been detected in coastal plankton in late spring when water temperature reached $15-16^{\circ} \mathrm{C}$.

\subsubsection{Species description}

Karlodinium gentienii is a nanoplanktonic and unarmored dinoflagellate. It is smallsized with an average length of $16.3 \pm 1.5 \mu \mathrm{m}$ (range 13.5-18.9 $\mu \mathrm{m}$ ) and an average width of $13.6 \pm 1.4 \mu \mathrm{m}$ (range 11.5-16.8 $\mu \mathrm{m})(\mathrm{n}=30)$. The median length to width ratio is 1.20 .

Light microscopy (LM): cells appear ovoid in outline (Fig. 4A-B), and barely flattened dorsoventrally. The epicone is conical in shape with the apical groove and the ventral pore at times discernible (Fig. 4A). The hypocone is hemispherical, not truncated by the sulcus. The cingulum is excavated and left-handed (Fig. 4B-C). The sulcus is wide (Fig. 4C). The nucleus is large, irregular in shape and is normally located in the approximate center of the cell (Fig. 4B, F). The chloroplasts (5-7) are yellow-green in colour (Fig. 4D), variable in shape (Fig. 4D, E-F), and distributed at the cell periphery. Refractive bodies are present (Fig. 4A, D).

Regarding the swimming behaviour, cells progress at moderate speed in a straight undulating line. Sometimes, they slow down to continue or change direction.

Scanning electron microscopy (SEM): using the first method of cell fixation based on osmium tetroxide as first fixative, SEM allowed to describe in more detail the external morphology of the cells observed in LM (Fig. 5A-F). The cingulum is displaced 25-31 $\%$ of the cell length (Fig. 5A). The sulcus extends from just above the antapex to the proximal end of the cingulum (Fig. $5 \mathrm{~A}$ ). It is wide in the hypocone with a pronounced left curvature at the level of the insertion of the longitudinal flagellum (Fig. 5F). It becomes narrower in the intercingular region where a tube-shaped structure between the two flagellar pores is present (Fig. 5F). Then, it invades slightly the epicone as a finger-like protusion, with a prominent right margin in the epicone (Fig. 5F). The apical groove is directed obliquely, starting ventrally above the anterior end of the sulcus and ending dorsally in the upper sixth of the epicone (Fig. 5A-C, E). It is linear to slightly curved and $0.3 \mu \mathrm{m}$ wide (Fig. $5 \mathrm{C}, \mathrm{E})$. An elongate ventral pore $(0.8-1.0 \mu \mathrm{m}$ in length) is present in the epicone, above the sulcal intrusion and close to the base of the apical groove (Fig. 5A, C).

When the membranous material or mucilage that covers the cell completely disappeared thanks to the second method of cell fixation using both a Lugol's solution and glutaraldehyde as fixatives, fine details of the cell surface are evident (Fig. 6A-G). The anterior side of the cingulum is delineated from the epicone by a list while its posterior border extends smoothly into the hypocone (Fig. 6A, C). The apical groove appears deep with thick margins (Fig. 6E). The amphiesmal vesicles, polygonal in shape, appear clearly all over on the cell, arranged in more or less distinct horizontal series (Fig. 6A-C). They are pentagonal or hexagonal except in the cingulum and along the apical groove where they tend to become quadrangular (Fig. 6F-G). They are arranged in 6 series on the epicone, 5 series on both the hypocone and the cingulum while the apical groove is lined on each side by one series. The surface of the epicone displays parallel furrows with tangential rows of rounded structures (number ca. 25 in $10 \mu \mathrm{m}$ and $150 \mathrm{~nm}$ in diameter) close to the crests (Fig. 6A, C-D). These arrangements are twisted in relation to the cell longitudinal axis. Below the cingulum, the surface displays two parallel rows of pustular micro-processes (sensu Paulmier et al., 1995) or two striae of knobs (sensu Siano et al., 2009), the upper one being just below the cingular edge and the second one ca. $1.5 \mu \mathrm{m}$ below (Fig. 6A, C, F). 
Transmission electron microscopy (TEM): the ultrastructure of the cells observed on the basis of cell sections shows that the nucleus occupies a large space in the cell, although it was not always well preserved by fixation (Fig. 7A-B). It is centrally located, extending into the epicone, as shown in LM (Fig. 4B, F). In some specimens, it appears to extend into the hypocone (Fig. 7A), probably when the cell is dividing. The chloroplasts contain 1-2 pyrenoids, putatively conical in shape since they appear lenticular when observed in longitudinal section (Fig. 7D) and triangular in cross section (Fig. 7E). In the amphiesma, the apical groove and the cingulum are apparent in longitudinal sections (Fig. 7A-B). Amphiesmal vesicles are not visible neither in longitudinal sections nor in cross sections, probably due to methods of fixation used for TEM. A semi-opaque material is present beneath the outer membrane, interrupted by lipidic droplets (Fig. 8F). Bundles of parallel microtubules are present in tangential sections through the cell surface (Fig. 8G). Plug-like structures were never observed after examinations of many cell sections. A conspicuous trichocyst system is revealed in all cell sections (Figs. 7A-C and $8 A-G$ ). It is particularly developed in the epicone, over the nucleus and, to a lesser extent in the hypocone, close to the cingulum (Fig. $7 A-B)$. The trichocysts are contained in long tubular cisternae that extend from the inner part of the cell towards the cell membrane (Figs. 7C and 8B). In their proximal part, the cisternae are filled with dense material surrounded by a double-membrane opaque wall (Fig. 8E). In the distal part of the cisternae, the trichocysts detach from the wall assuming a quadrangular shape (Fig $8 \mathrm{C}$ ). Lid-like structures cover the trichocyst exits (Fig. 8D) which are raised when the trichocysts are discharged (Figs. 7C and 8E). The number and the size of the lids (approximately 25 in $10 \mu \mathrm{m}$ and $150 \mathrm{~nm}$ in diameter respectively) match those of the rounded structures observed in SEM. A conspicuous pusule system is associated to the flagellar apparatus (Fig. 7F-G). It is composed of tubes of two main size classes (approximately $0.2 \mu \mathrm{m}$ and $0.08 \mu \mathrm{m}$ in diameter); the larger tubes have a bright appearing lumen and a very thin external layer of dark material, conversely smaller tubes have a darker lumen (Fig. 7F-G). The flagellar apparatus was not integrally visible in our preparations, only one flagellar base and a striated root, likely $r 4$ (sensu Bergholtz et al., 2005), is clearly visible.

\subsubsection{Phylogeny of Karlodinium gentienii}

Phylogenetic analysis using ML methods (Fig. 2) showed that sequences of Karlodinium gentienii (from natural sample and culture) formed a well-supported independent clade (100 LBS, 1.00 BPP), clustering with $K$. ballantinum and the unspecified Karlodinium from Korea (strain KAMS0708), with high support (100 LBS, $1.00 \mathrm{BPP}$ ). The estimated genetic distances between $K$. gentienii and its closest related $K$. ballantinum and $K$. sp. from Korea were $2.8 \%$ and $2.7 \%$ respectively while the average among the species of Karlodinium ranged from $2.0 \%$ to $9.9 \%$ (Table 2).

\subsubsection{Pigment profile}

HPLC analyses of an autotrophically grown culture of Karlodinium gentienii revealed the presence of major pigments typical of fucoxanthin containing dinoflagellates with chloroplast Type 3, as described by Zapata et al. (2012) (Fig. 9). The results showed that Karlodinium gentienii contains $\mathrm{chl} \mathrm{c}_{2}$ and $\mathrm{c}_{3}$. The major carotenoid was fucoxanthin, along with moderate amounts of the two derivatives 19'butanoyloxyfucoxanthin and 19'-hexanoyloxyfucoxanthin. A xanthophyll exhibiting similar absorption properties to an acyl-fucoxanthin compound eluted at 23 min. The photoprotective diadinoxanthin and diatoxanthin were also detected in significant amounts, as well as an unknown xanthophyll absorbing maximally at $442 \mathrm{~nm}$ and eluting at $19 \mathrm{~min}$. No gyroxanthin-diester or gyroxanthin-like pigments and non polarchl $c_{2}$ were detected. 


\subsubsection{Haemolytic activity}

The preliminary assays showed that Karlodinium gentienii had a haemolytic activity. With a cell concentration of $20 \times 10^{3}$ cells $\mathrm{mL}^{-1}$, an haemolysis of $2 \%$ was found with Karlodinium gentienii while $40 \%$ of the erythrocytes were lysed with Karlodinium armiger. A second analysis with a concentration of $70 \times 10^{3}$ cells $\mathrm{mL}^{-1}$ of K. gentienii showed a lysis of $80 \%$ of the erythrocytes.

\section{Discussion}

\subsubsection{Genetic diversity of Kareniaceae}

The molecular phylogenetic approach revealed a notable diversity of Kareniaceae in France including 13 taxonomic units. The unidentified Kareniaceae from the Atlantic (Fig. 1N-P) occupied the same phylogenetic position in our two ML trees (Figs. 2-3). It was distant from Karlodinium antarcticum (Fig. 2) and clustered with the Dinophyceae sp. from Ross Sea (Fig. 3). On this basis, we consider that the French unidentified Kareniaceae, together with the Dinophyceae sp. from Ross Sea, is distinct from $K$. antarcticum in spite of their resemblance as emphasized by de Salas et al. (2008) for the Dinophyceae sp. from Antarctica. According to our data, they likely belong to a novel genus, as already suggested by Gast et al. (2006). However, more data are needed before deciding conspecificity or discrimination between these two taxa.

Our survey confirmed the presence of Karenia mikimotoi and $K$. papilionacea on the French Atlantic coast and revealed for the first time the presence of both $K$. brevisulcata, previously recorded as Gymnodinium brevisulcatum (Chang, 1999) and K. umbella (de Salas et al., 2004). The latter two species have been described in New Zealand and Australia respectively, and do not seem to have been reported elsewhere. For the genus Karlodinium, $K$. decipiens was genetically detected in the Atlantic while the two potentially ichthyologic species $K$. armiger and $K$. veneficum were in both the Atlantic and Corsica. If $K$. veneficum is distributed worldwide, $K$. decipiens was reported only in Australian and Spanish Atlantic waters before and K. armiger was only known from the type locality Alfacs Bay (Spain) in NW Mediterranean.

The remaining taxa could not be identified at species-level, except for the sister taxon of $K$. ballantinum described in this paper. Concerning Karenia sp1 (Fig. 1G), the sister taxon of $K$. papilionacea, the branch length and the pairwise genetic distance between these two taxa (Fig. 2 and Table 2) seem to argue in favour of two distinct species unlike Karenia sp2 (Fig. 1E-F) which could be conspecific with K. umbella. Indeed, the $p$-distance between the two latter taxa was less than the maximum value of the interspecific variability between individuals of a same species. In order to resolve this taxonomic issue, a SEM examination of the Corsican strain of Karenia sp2 would be necessary to search for the characteristic furrows of $K$. umbella. As to Karlodinium sp. (Fig. 1L), the sister taxon to $K$. corrugatum, the sequence divergence between these two taxa was higher than the minimum value of the interspecific variability between Karlodinim species, suggesting separate species. However, further genetic and morphological investigations relative to these three unidentified Kareniaceae species are needed to assert all these assumptions. Finally, regarding the taxon Takayama sp. (Fig. $1 \mathrm{M}$ ), the closest related to T. tasmanica, the genetic distance between these two taxa was low $(0.4 \%)$, which could mean that they were conspecific. However, De Salas et al. (2008) pointed out some variability in the same order of magnitude between species within the genus Takayama. In addition, Gu et al. (2013) indicated that the LSU rDNA gene may be too conservative in this genus, as in other 
dinoflagellate groups. As a consequence, the French Takayama species was considered as unidentified until additional genetic and morphological data.

\subsection{Characterization of Karlodinium gentienii}

\subsubsection{Morphological and genetic comparisons}

Karlodinium gentienii was separated from the other species of Karlodinium, based on morphology, molecular phylogeny, and genetic data (Tables 2 and 3 and Fig. 2).

Morphological differences exist between $K$. gentienii and the other described Karlodinium species (Table 3). At the surface of the epicone of $K$. gentienii, the set of parallel spiral furrows was similar to that described for $K$. corrugatum. However, the location of the ventral pore well away from the sulcus distinguishes $K$. corrugatum (de Salas et al., 2008) from the new species. In addition, rounded episomic structures were aligned along the furrows in $K$. gentienii unlike in $K$. armiger where they are randomly placed (Bergholtz et al., 2005). These structures were also observed as two parallel rows below the cingulum of $K$. gentienii like $K$. corsicum (Paulmier et al., 1995). However, these two taxa differed in the cell length, the girdle displacement, the number and the color of chloroplasts. And, the micro-pustules arranged in two longitudinal rows in the cingulum as described by Paulmier et al. (1995) for $K$. corsicum were not observed in the new species. Another species $K$. ballantinum was also described with two rows of rounded structures (striae of knobs) but a single row was hyposomic, the other one being episomic (de Salas et al., 2008; Siano et al., 2009). The intercingular tube-shaped structure in the sulcus of $K$. gentienii has also been reported in $K$. australe (de Salas et al., 2005) and K. ballantinum (de Salas et al., 2008) and may be homologous with the putative "platelet" of $K$. corsicum (Paulmier et al., 1995) or peduncle of $K$. veneficum (Taylor, 1992). This structure is common to the species of Karenia and Takayama (Haywood et al., 2004; Gu et al., 2013) and has been also observed in Asterodinium gracile, a putative member of the Kareniaceae together with Brachidinium capitatum (Gómez et al., 2005; Henrichs et al., 2011). Accordingly, this character might be common to all species of Kareniaceae, as suggested by Haywood et al. (2004). The arrays of plug-like structures immediately below the amphiesma have not been observed in $K$. gentienii, despite many cell sections. Considering that cells lost most of the amphiesma when fixed for TEM, it is difficult to determine on the presence or absence of plug-like structures. Dischargeable trichocysts were particularly numerous both in the epicone and below the cingulum of $K$. gentienii in contrast to $K$. armiger where they are limited to the epicone (Bergholtz et al., 2005). Interestingly, both the lids of the trichocyst-containing cisternae and the external micro-structures were similar in number and size in K. gentienii, suggesting that the arrays of trichocysts observed in TEM match the rows of micro-processes observed on the cell surface in SEM. This correspondence was made possible thanks to the clear visualization of micro-processes, using a suitable preservation method to remove the outer membrane of the cells.

The phylogenetic position of $K$. gentienii together with $K$. ballantinum and $K$. sp. from Korea in a strongly supported clade and the pairwise distances between $K$. gentienii and its two sister taxa support also the erection of $K$. gentienii as a new species.

\subsubsection{Pigment composition}

The pigmentation of only four species of Karlodinium has been described to date and the variable part of the pigmentation among these species seems to rely mostly on the 
presence/absence of gyroxanthin derivatives and non polar-chl $c_{2}$ compounds. All analyzed strains of the most studied species, $K$. veneficum, contain gyroxanthin esters in significant amounts and no non polar-chl $c_{2}$ (Kempton et al., 2002; Garcés et al., 2006; Bachvaroff et al., 2009; Zapata et al., 2012) (Table S2). By contrast, the strain of $K$. australe analyzed by de Salas et al. (2005) did not synthesize any gyroxanthin derivative but did contain non polar-chl $c_{2}$ eluting after chl a. In $K$. armiger and $K$. decipiens strains, both pigments are usually present (Bergholtz et al., 2005; Garcés et al., 2006; Zapata et al., 2012). The novel species described here, Karlodinium gentienii, contained neither gyroxanthin derivatives nor non polar-chl $c_{2}$ compounds and thus shows a new combination of pigments in the Karlodinium genus.

\subsubsection{Haemolytic activity}

Although a haemolytic activity has been found with Karlodinium gentienii, it appears lower than with $K$. armiger, which has been proven to be ichthyologic (Garcés et al., 2006). Nevertheless, further analyses are necessary to measure comparatively with more cells concentrations, and investigate several other strains and species.

\section{Conclusions}

Even though one genus and several species remain to be identified, requiring new attempts of cultivation, this study strengthens our knowledge of the diversity of Kareniaceae in France, with the certainty of a novel genus and the description of a new potentially toxic species: Karlodinium gentienii. Future works should focus on the geographic distribution of Kareniaceae species and, especially the new potentially toxic species $K$. gentienii, by further investigating the waters from the English Channel and the Mediterranean Sea. Pigment analyses showed that gyroxanthin and non polar chl $c_{2}$ compounds appeared to constitute a relevant criterion for the delineation of Karlodinium species. It would therefore be worth exploring the pigmentation of the other Karlodinium species in detail in the future. At last, characterization of haemolytic compounds and toxins should be undertaken in order to assess the potential risks induced by Karlodinium gentienii in the field.

\section{Acknowledgements}

We are grateful to Yoann Baldi for providing Corsican samples. Thanks to Evelyne Erard-Le Denn who isolated Karenia mikimotoi for culturing (strain GATIN95), and Laureline Le Montagner who isolated K. mikimotoi and K. umbella from Saint Pierre and Miquelon for molecular analysis (GenBank accession numbers KJ508364 and KJ508372). The Roscoff Culture Collection is warmly thanked for the maintenance of the Karlodinium veneficum strain RCC2539, as well as S. Ota who isolated it. Financial support was provided by IFREMER through the project DIALTOXE (Diversite algale, efflorescences toxiques, eutrophisation). 


\section{References}

Arzul, G., Gentien, P., Crassous, M.-P., 1994. A haemolytic test to assay toxins excreted by the marine dinoflagellate Gyrodinium cf. aureolum. Water Research 28(4), 961-965.

Arzul, G., Belin, C., Nézan, E., 1995. Ichthyotoxic events associated with Gymnodinium cf. nagasakiense on the Atlantic coast of France. Harmful Algae News 12-13, 8-9.

Bachvaroff, T.R., Adolf, J.E., Place, A.R., 2009. Strain variation in Karlodinium veneficum (Dinophyceae): Toxin profiles, pigments, and growth characteristics. J. Phycol. 45(1), 137-153.

Bergholtz, T., Daugbjerg, N., Moestrup, Ø., Fernández-Tejedor, M., 2005. On the identity of Karlodinium veneficum and description of Karlodinium armiger sp. nov. (Dinophyceae), based on light and electron microscopy, nuclear-encoded LSU rDNA, and pigment composition. J. Phycol. 42, 170-193.

Bodennec, G., Arzul, G., Erard le Denn, E., Gentien, P., 1994. Gymnodinium sp. dans l'étang de Diane (Corse) septembre - octobre 1993. Tests biologiques et analyses chimiques. DEL/94.07/Brest. Ifremer, Brest, p. 26.

Chang, F.H., 1999. Gymnodinium brevisulcatum sp. nov. (Gymnodiniales, Dinophyceae), a new species isolated from the 1998 summer toxic bloom in Wellington Harbor, New Zealand. Phycologia 38, 377-384.

Chomérat, N., Couté, A., 2008. Protoperidinium bolmonense sp. nov. (Peridiniales, Dinophyceae), a small dinoflagellate from a brackish hypereutrophic lagoon (South of France). Phycologia 47(4), 392-403.

Clément, A., Seguel, M., Arzul, G., Guzmán, L., Alarcon, C., 2001. Widespread outbreak of a haemolytic, ichtyotoxic Gymnodinium sp. in Southern Chile, In: Hallegraeff, G.M., Blackburn, S.I., Bolch, C.J., Lewis, R.J. (Eds.), Ninth International Conference on Harmful Algal Blooms, 7-11 February 2000, Hobart, Australia. International Oceanographic Commission of UNESCO, Paris, pp. 66-69.

Couté, A., 2002. Biologie et microscopie électronique à balayage. Mémoires de la SEF $6,31-44$.

Dahl, E., Tangen, K., 1993. 25 years experience with Gyrodinium aureolum in Norwegian waters, In: Smayda, T.J., Shimizu, Y. (Eds.), Toxic phytoplankton blooms in the Sea. Elsevier Science Publishers, B.V., Amsterdam, pp. 15-21.

Daugbjerg, N., Hansen, G., Larsen, J., Moestrup, Ø., 2000. Phylogeny of some of the major genera of dinoflagellates based on ultrastructure and partial LSU rDNA sequence data, including the erection of three new genera of unarmoured dinoflagellates. Phycologia 39(4), 302-317.

de Salas, M., Bolch, C.J., Botes, L., Nash, G., Wright, S.W., Hallegraeff, G., 2003. Takayama gen. nov. (Gymnodiniales, Dinophyceae), a new genus of unarmored dinoflagellates with sigmoid apical grooves, including the description of two new species. J. Phycol. 39, 1233-1246.

de Salas, M., Bolch, C., Hallegraeff, G., 2004. Karenia umbella sp. nov. (Gymnodiniales, Dinophyceae), a new potentially ichthyotoxic dinoflagellate species from Tasmania, Australia. Phycologia 43(2), 166-175. 
de Salas, M., Bolch, C.J., Hallegraeff, G., 2005. Karlodinium australe sp. nov. (Gymnodiniales, Dinophyceae), a new potentially ichthyotoxic unarmoured dinoflagellate from lagoonal habitats of south-eastern Australia. Phycologia 44(6), 640650.

de Salas, M., Laza-Martínez, A., Hallegraeff, G., 2008. Novel unarmoured dinoflagellates from the toxigenic family Kareniaceae (Gymnodiniales): five new species of Karlodinium and one new Takayama from the Australian sector of the Southern Ocean. J. Phycol. 44, 241-257.

Deeds, J.R., Terlizzi, D.E., Adolf, J.E., Stoecker, D.K., Place, A.R., 2002. Toxic activity from cultures of Karlodinium micrum (=Gyrodinium galatheanum) (Dinophyceae) - a dinoflagellate associated with fish mortalities in an estuarine aquaculture facility. Harmful Algae 1, 169-189.

Edgar, R.C., 2004. MUSCLE: a multiple sequence alignment method with reduced time and space complexity. BMC Bioinformatics 5, 113.

Eschbach, E., Scharsack, J.P., John, U., Medlin, L.K., 2001. Improved erythrocyte lysis assay in microtitre plates for sensitive detection and efficient measurement of haemolytic compounds from ichthyotoxic algae. Journal of applied toxicology : JAT $21(6), 513-519$.

Garcés, E., Fernandez, M., Penna, A., van Lenning, K., Gutierrez, A., Camp, J., Zapata, M., 2006. Characterization of NW Mediterranean Karlodinium spp. (Dinophyceae) strains using morphological, molecular, chemical, and physiological methodologies. J. Phycol. 42, 1096-1112.

Gast, R.J., Moran, D.M., Beaudoin, D.J., Blythe, J.N., Dennett, M.R., Caron, D.A., 2006. Abundance of a novel dinoflagellate phylotype in the Ross Sea, Antarctica. J. Phycol. 42, 233-242.

Gentien, P., Lazure, P., Raffin, B., 1998. Effect of meteorological conditions in spring on the extent of a Gymnodinium cf. nagasakiense bloom, In: Reguera, B., Blanco, J., Fernández, M.L., Wyatt, T. (Eds.), 8th International Conference on Harmful Algae. Xunta de Galicia and Intergovernmental Oceanographic Commission of UNESCO, Paris.

Gómez, F., Nagahama, Y., Takayama, H., Furuya, K., 2005. Is Karenia a synonym of Asterodinium-Brachidinium (Gymnodiniales, Dinophyceae)? Acta Bot. Croat. 64(2), 263-274.

Gu, H., Luo, Z., Zhang, X., Xu, B., Fang, Q., 2013. Morphology, ultrastructure and phylogeny of Takayama xiamenensis sp. nov. (Gymnodiniales, Dinophyceae) from the East China Sea. Phycologia 52(3), 256-265.

Guillou, L., Nézan, E., Cueff, V., Erard-Le Denn, E., Cambon-Bonavita, M.A., Gentien, P., Barbier, G., 2002. Genetic diversity and molecular detection of three toxic dinoflagellate genera (Alexandrium, Dinophysis, and Karenia) from French coasts. Protist 153(3), 223-238.

Guindon, S., Gascuel, O., 2003. A simple, fast, and accurate algorithm to estimate large phylogenies by maximum likelihood. Syst. Biol. 52(5), 696-704. 
Hall, T.A., 1999. BioEdit: a user-friendly biological sequence alignment editor and analysis program for Windows 95/98/NT. Nucleic Acids Symp. Ser. 41, 95-98.

Hallegraeff, G.M., 2002. Aquaculturists' guide to harmful Australian microalgae. Print Centre, Hobart, Australia.

Hallegraeff, G.M., Mooney, B., Evans, K., 2010. What triggers fish-killing Karlodinium veneficum dinoflagellate blooms in the Swan Canning River system? Final report SRT project no. RSG09TAS01. Swan Canning Research and Innovation Program, pp. 1-30.

Haywood, A.J., Steidinger, K.A., Truby, E.W., 2004. Comparative morphology and molecular phylogenetic analysis of three new species of the genus Karenia (Dinophyceae) from New Zealand. J. Phycol. 40, 165-179.

Henrichs, D.W., Sosik, H.M., Olson, R.J., Campbell, L., 2011. Phylogenetic analysis of Brachidinium capitatum (Dinophyceae) from the Gulf of Mexico indicates membership in the Kareniaceae. J. Phycol. 47, 366-374.

Keller, M.D., Selvin, R.C., Claus, W., Guillard, R.R.L., 1987. Media for the culture of oceanic ultraphytoplankton. J. Phycol. 23, 633-638.

Kempton, J.W., Lewitus, A.J., Deeds, J.R., McHugh Law, J., Place, A.R., 2002. Toxicity of Karlodinium micrum (Dinophyceae) associated with a fish kill in a South Carolina brackish retention pond. Harmful Algae 1, 233-241.

Landsberg, J.H., Steidinger, K.A., 1998. A historical review of Gymnodinium breve red tides implicated in mass mortalities of the manatee (Trichechus manatus latirostris) in Florida, USA., In: Reguera, B., Blanco, J., Fernández, M.L., Wyatt, T. (Eds.), Proceedings of the VIII International conference on Harmful Algae, Vigo, Spain, 25-29 June 1997. Xunta de Galicia and Intergovernmental Oceanographic Commission of UNESCO, Paris, pp. 97-100.

Loyer, S., Lazure, P., Gentien, P., Menesguen, A., 2001. Modelling of Gymnodinium mikimotoi blooms along the French Atlantic coast: geographical and vertical distributions. Hydroécologie Appliquée 13(1), 57-76.

Medhioub, A., Medhioub, W., Amzil, Z., Sibat, M., Bardouil, M., Ben Neila, I., Mezghani, S., Hamza, A., Lassus, P., 2009. Influence of environmental parameters on Karenia selliformis toxin content in culture. Cah. Biol. Mar. 50, 333-342.

Morin, P., Birrien, J.-L., Le Corre, P., 1989. The frontal systems in the Iroise Sea: development of Gyrodinium aureolum Hulburt on the inner front. Sci. Mar. 53(2-3), 215221.

Nézan, E., 1998. Recurrent observations of a Gymnodinium breve-like species. Harmful Algae News 17, 7.

Nézan, E., Tillmann, U., Bilien, G.I., Boulben, S., Chèze, K., Zentz, F., Salas, R., Chomérat, N., 2012. Taxonomic revision of the dinoflagellate Amphidoma caudata: Transfer to the genus Azadinium (Dinophyceae) and proposal of two varieties, based on morphological and molecular phylogenetic analyses. J. Phycol. 48(4), 925-939.

Partensky, F., Gentien, P., Sournia, A., 1991. Gymnodinium cf. nagasakiense = Gyrodinium cf. aureolum (Dinophycées), In: Sournia, A., Belin, C., Berland, B., Erard le Denn, E., Gentien, P., Grzebyk, D., Marcaillou le Baut, C., Lassus, P., Partensky, F. 
(Eds.), Le phytoplancton nuisible des côtes de France : de la biologie à la prévention. CNRS - Ifremer, Plouzané, pp. 63-82.

Paulmier, G., Berland, B., Billard, C., Nézan, E., 1995. Gyrodinium corsicum nov. sp. (Gymnodiniales, Dinophycées), organisme responsable d'une "eau verte" dans l'étang marin de Diana (Corse) en avril 1994. Cryptog. Algol. 16(2), 77-94.

Place, A.R., Bowers, H.A., Bachvaroff, T.R., Adolf, J.E., Deeds, J.R., Sheng, J., 2012. Karlodinium veneficum - The little dinoflagellate with a big bite. Harmful Algae 14, 179-195.

Posada, D., 2008. jModelTest: Phylogenetic model averaging. Mol. Biol. Evol. 25(7), 1253-1256.

Rasband, W.S., 1997-2006. ImageJ, 1.37c ed. National Institutes of Health, Bethesda, Maryland.

Reguera, B., Smayda, T.J., 2012. In memoriam: Tribute to Patrick Gentien (29 November 1950-9 May 2010). Harmful Algae 14, 5-9.

Repeta, D.J., Bjørnland, T., 1997. Preparation of carotenoid standards, In: Jeffrey, S.W., Mantoura, R.F.C., Wright, S.W. (Eds.), Phytoplankton pigments in oceanography: guidelines to modern methods. UNESCO, Paris, pp. 239-260.

Ronquist, F., Huelsenbeck, J.P., 2003. MrBayes 3: Bayesian phylogenetic inference under mixed models. Bioinformatics 19(12), 1572-1574.

Roy, S., Llewellyn, C.A., Egland, E.S., Johnsen, G., 2011. Phytoplankton pigments, characterization, chemotaxonomy, and applications in oceanography. Cambridge University Press, Cambridge, UK.

Siano, R., Kooistra, W.H.C.F., Montresor, M., Zingone, A., 2009. Unarmoured and thinwalled dinoflagellates from the Gulf of Naples, with the description of Woloszynskia cincta sp. nov. (Dinophyceae, Suessiales). Phycologia 48(1), 44-65.

Six, C., Worden, A.Z., Rodríguez, F., Moreau, H., Partensky, F., 2005. New insights into the nature and phylogeny of Prasinophyte antenna proteins: Ostreococcus tauri, a a case study. Mol. Biol. Evol. 22(11), 2217-2230.

Takayama, H., Adachi, R., 1984. Gymnodinium nagasakiense sp. nov., a red tide forming dinophyte in the adjacent waters of Japan. Bull. Plankton Soc. Jpn. 31, 7-14.

Tamura, K., Peterson, D., Peterson, N., Stecher, G., Nei, M., Kumar, S., 2011. MEGA5: Molecular Evolutionary Genetics Analysis using Maximum Likelihood, evolutionary distance, and Maximum Parsimony methods. Mol. Biol. Evol. 28(10), 2731-2739.

Taylor, F.J.R., 1992. The taxonomy of harmful marine phytoplankton. G. bot. ital. 126, 209-219.

Vanhoutte-Brunier, A., Fernand, L., Ménesguen, A., Lyons, S., Gohin, F., Cugier, P., 2008. Modelling the Karenia mikimotoi bloom that occurred in the western English Channel during summer 2003. Ecological Modelling 210(4), 351-376.

Zapata, M., Garrido, J.L., 1991. Influence of injection conditions in reversed-phase high-performance liquid chromatography of chlorophylls and carotenoids. Chromatographia 31(11-12), 589-594. 
Zapata, M., Rodríguez, F., Garrido, J.L., 2000. Separation of chlorophylls and carotenoids from marine phytoplankton: a new HPLC method using a reversed phase $\mathrm{C}_{8}$ column and pyridinecontaining mobile phases. Mar. Ecol. Prog. Ser. 195, 29-45.

Zapata, M., Fraga, S., Rodríguez, F., Garrido, J.L., 2012. Pigment-based chloroplast types in dinoflagellates. Mar. Ecol. Prog. Ser. 465, 33-52.

Table 1. List of new sequence data from French specimens of Kareniaceae used for phylogenetic analysis. Area and date of collection, isolate and accession numbers are provided.

\begin{tabular}{|c|c|c|c|c|}
\hline Taxon & $\begin{array}{c}\text { Collection } \\
\text { Area }^{*}\end{array}$ & $\begin{array}{c}\text { Collection } \\
\text { date }^{\star \star}\end{array}$ & $\begin{array}{c}\text { Isolate } \\
\text { no. }\end{array}$ & $\begin{array}{c}\text { GenBank } \\
\text { no. }\end{array}$ \\
\hline Karenia brevisulcata & $\begin{array}{c}\text { Atlantic coast } \\
(47.837 \mathrm{~N}-3.950 \\
\text { W) }\end{array}$ & $\begin{array}{c}11 \text { Aug. } 2009 \\
\left(17.3^{\circ} \mathrm{C}\right)\end{array}$ & IFR1133 & KJ508359 \\
\hline \multirow[t]{3}{*}{ Karenia mikimotoi } & $\begin{array}{l}\text { Mediterranean } \\
\text { coast } \\
(43.456 \mathrm{~N} 4.497 \\
\text { W) }\end{array}$ & $\begin{array}{c}25 \text { May } 2009 \\
\left(23.9^{\circ} \mathrm{C}\right)\end{array}$ & IFR980 & KJ508361 \\
\hline & $\begin{array}{l}\text { Atlantic coast } \\
(48.335 \mathrm{~N}-4.366 \\
\text { W) }\end{array}$ & $\begin{array}{c}18 \text { Aug. } 1995 \\
\text { (n. a.) }\end{array}$ & GATIN95 & KJ508362 \\
\hline & $\begin{array}{l}\text { Atlantic coast } \\
(47.837 \mathrm{~N}-3.950 \\
\text { W) }\end{array}$ & $\begin{array}{c}23 \text { April } 2008 \\
\left(11.7^{\circ} \mathrm{C}\right)\end{array}$ & IFR559 & KJ508363 \\
\hline Karenia papilionacea & $\begin{array}{l}\text { Atlantic coast } \\
(48.163 \mathrm{~N}-4.392 \\
\text { W) }\end{array}$ & $\begin{array}{c}31 \text { July } 2007 \\
\left(17.9^{\circ} \mathrm{C}\right)\end{array}$ & IFR562 & KJ508366 \\
\hline Karenia umbella & $\begin{array}{l}\text { Atlantic coast } \\
(48.163 \mathrm{~N}-4.392 \\
\text { W) }\end{array}$ & $\begin{array}{c}30 \text { June } 2008 \\
\left(19.8^{\circ} \mathrm{C}\right)\end{array}$ & IFR644 & KJ508368 \\
\hline
\end{tabular}




\begin{tabular}{|c|c|c|c|c|}
\hline \multirow[t]{2}{*}{ Karenia sp1 } & $\begin{array}{l}\text { Atlantic coast } \\
(48.163 \mathrm{~N}-4.392 \\
\text { W) }\end{array}$ & $\begin{array}{c}31 \text { July } 2007 \\
\left(17.9^{\circ} \mathrm{C}\right)\end{array}$ & IFR528 & KJ508373 \\
\hline & $\begin{array}{l}\text { Atlantic coast } \\
(47.837 \mathrm{~N}-3.950 \\
\text { W) }\end{array}$ & $\begin{array}{c}19 \text { June } 2007 \\
\left(16.6^{\circ} \mathrm{C}\right)\end{array}$ & IFR572 & KJ508374 \\
\hline \multirow[t]{2}{*}{ Karenia sp2 } & $\begin{array}{l}\text { Mediterranean } \\
\text { lagoon } \\
(42.872 \mathrm{~N} 3.014 \\
\text { W) }\end{array}$ & $\begin{array}{c}23 \text { April } 2007 \\
\left(20.2^{\circ} \mathrm{C}\right)\end{array}$ & IFR868 & KJ508369 \\
\hline & $\begin{array}{l}\text { Mediterranean } \\
\text { lagoon } \\
(42.967 \mathrm{~N} 3.007 \\
\text { W) }\end{array}$ & $\begin{array}{c}28 \text { Oct. } 2009 \\
\left(15.8^{\circ} \mathrm{C}\right)\end{array}$ & IFR1186 & KJ508370 \\
\hline
\end{tabular}

Corsican lagoon 13 May 2013 IFR-KUM- KJ508371 $\left(42.046 \mathrm{~N} 9.478 \quad\left(22.7^{\circ} \mathrm{C}\right) \quad 01 \mathrm{U}\right.$

W)

Karlodinium armiger

Corsican lagoon

27 May 2013 IFR-KAR- KJ508375

$(42.128 N 9.529$
W)

$\left(19.4^{\circ} \mathrm{C}\right) \quad 01 \mathrm{D}$

Atlantic coast

14 June 2010 IFR10-093 KJ508376

$(48.163 N-4.392$

W)

$\left(15.6^{\circ} \mathrm{C}\right)$

Karlodinium decipiens

Atlantic coast

07 June 2010

IFR10-069

KJ508377

$(48.335 \mathrm{~N}-4.366$

W)

$\left(15.5^{\circ} \mathrm{C}\right)$ 


\begin{tabular}{|c|c|c|c|c|}
\hline \multirow[t]{2}{*}{ Karlodinium gentienii } & $\begin{array}{l}\text { Atlantic coast } \\
(48.335 \mathrm{~N}-4.366 \\
\text { W) }\end{array}$ & $\begin{array}{l}07 \text { June } 2010 \\
\left(15.5^{\circ} \mathrm{C}\right)\end{array}$ & IFR10-074 & KJ508378 \\
\hline & $\begin{array}{l}\text { Atlantic coast } \\
(47.837 \mathrm{~N}-3.950 \\
\text { W) }\end{array}$ & $\begin{array}{l}02 \text { July } 2012 \\
\left(16.1^{\circ} \mathrm{C}\right)\end{array}$ & $\begin{array}{l}\text { IFR-KGE- } \\
\text { 01C }\end{array}$ & KJ508379 \\
\hline \multirow[t]{3}{*}{ Karlodinium veneficum } & $\begin{array}{l}\text { Atlantic coast } \\
(48.256 \text { N }-4.557 \\
\text { W) }\end{array}$ & $\begin{array}{l}19 \text { July } 2010 \\
\left(18.6^{\circ} \mathrm{C}\right)\end{array}$ & IFR10-150 & KJ508380 \\
\hline & $\begin{array}{l}\text { Corsican lagoon } \\
(42.128 \text { N } 9.529 \\
\text { W) }\end{array}$ & $\begin{array}{c}27 \text { May } 2013 \\
\left(19.4^{\circ} \mathrm{C}\right)\end{array}$ & $\begin{array}{l}\text { IFR-KVE- } \\
\text { 01D }\end{array}$ & KJ508381 \\
\hline & $\begin{array}{l}\text { Atlantic coast } \\
(48.163 \mathrm{~N}-4.392 \\
\text { W) }\end{array}$ & $\begin{array}{c}14 \text { June } 2010 \\
\left(15.6^{\circ} \mathrm{C}\right)\end{array}$ & IFR10-101 & KJ508382 \\
\hline \multirow[t]{2}{*}{ Karlodinium sp. } & $\begin{array}{l}\text { Atlantic coast } \\
(48.163 \mathrm{~N}-4.392 \\
\text { W) }\end{array}$ & $\begin{array}{c}15 \text { July } 2008 \\
\left(18.9^{\circ} \mathrm{C}\right)\end{array}$ & IFR797 & KJ508385 \\
\hline & $\begin{array}{l}\text { Mediterranean } \\
\text { coast } \\
(43.456 \mathrm{~N} 4.497 \\
\text { W) }\end{array}$ & $\begin{array}{c}25 \text { May } 2009 \\
\left(23.9^{\circ} \mathrm{C}\right)\end{array}$ & IFR981 & KJ508386 \\
\hline \multirow[t]{2}{*}{ Takayama sp. } & $\begin{array}{l}\text { Atlantic coast } \\
(47.535 \mathrm{~N}-3.094 \\
\text { W) }\end{array}$ & $\begin{array}{l}23 \text { June } 2008 \\
\left(16.6^{\circ} \mathrm{C}\right)\end{array}$ & IFR863 & KJ508387 \\
\hline & $\begin{array}{l}\text { Atlantic coast } \\
\left(\begin{array}{c}47.535 \mathrm{~N}-3.094 \\
\text { W) }\end{array}\right.\end{array}$ & $\begin{array}{l}23 \text { June } 2008 \\
\qquad\left(16.6^{\circ} \mathrm{C}\right)\end{array}$ & IFR909 & KJ508388 \\
\hline
\end{tabular}




$\begin{array}{ccccc}\text { Kareniaceae sp. } & \text { Atlantic coast } & 20 \text { April } 2010 & \text { IFR11-001 } & \text { KJ508389 } \\ (47.837 \mathrm{~N}-3.950 & \left(11.7^{\circ} \mathrm{C}\right) & & \\ \mathrm{W}) & & & \\ \text { Atlantic coast } & 20 \text { April } 2010 & \text { IFR11-015 } & \text { KJ508390 } \\ (47.837 \mathrm{~N}-3.950 & \left(11.7^{\circ} \mathrm{C}\right) & & \\ \mathrm{W}) & & & \\ \text { Atlantic coast } & 20 \text { April } 2010 & \text { IFR10-474 } & \text { KJ858681 } \\ (47.837 \mathrm{~N}-3.950 & \left(11.7^{\circ} \mathrm{C}\right) & & \\ \mathrm{W}) & & & \end{array}$

In brackets: ${ }^{*}$ geographic coordinates, ${ }^{* *}$ seawater temperature, n.a.: not available. 


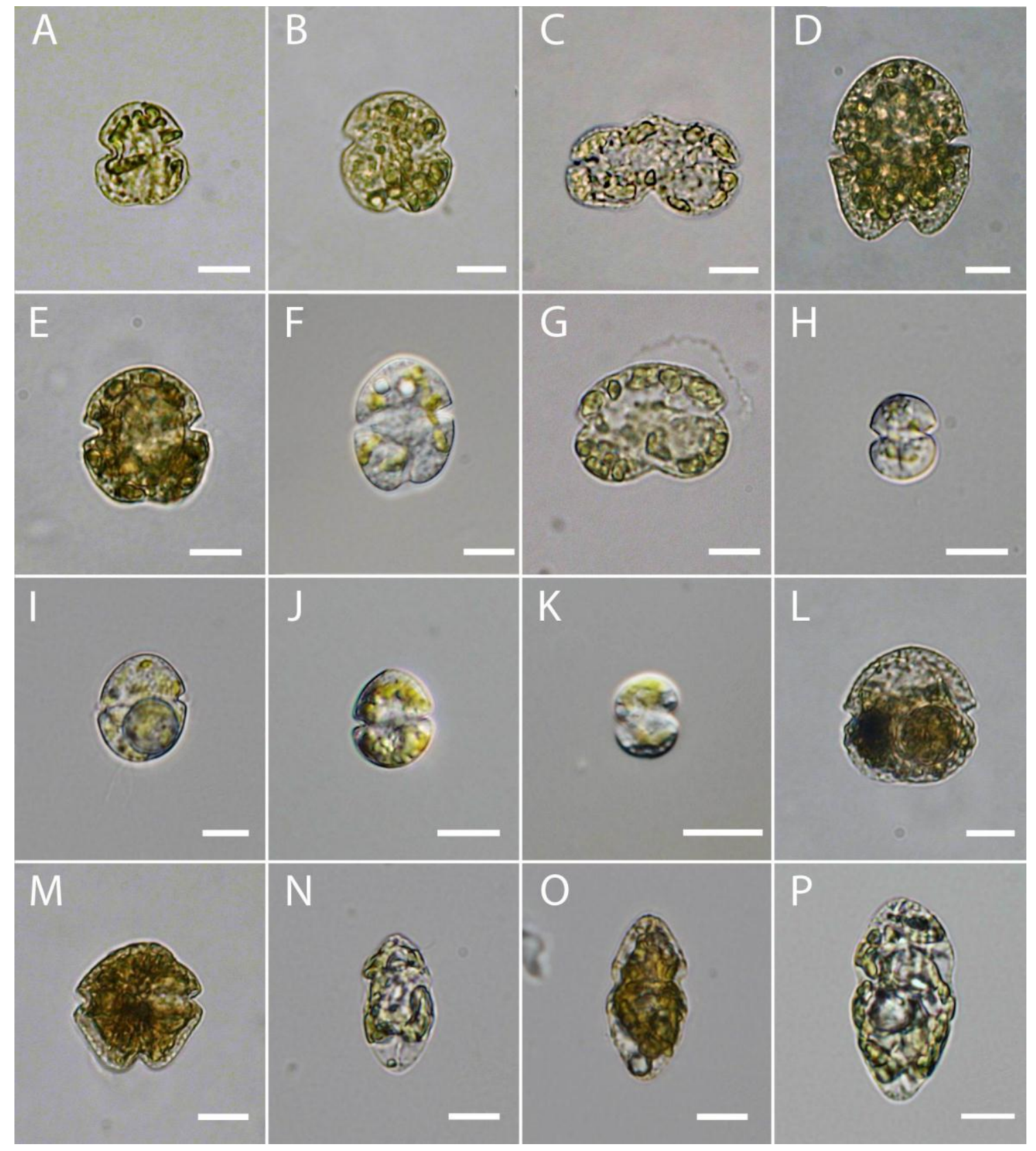

Fig. 1. Light micrographs of some specimens of Kareniaceae used for single-cell PCR analysis, with GenBank accession numbers in square brackets. (A) Karenia brevisulcata [KJ508359]. (B) K. mikimotoi [KJ508363]. (C) K. papilionacea [KJ508366]. (D) K. umbella. [KJ508368]. (E-F) Karenia sp2. (E) [KJ508370]. (F) [KJ508371]. (G) Karenia sp1. [KJ508373]. (H) Karlodinium armiger [KJ508375]. (I) K. decipiens [KJ508377]. (J) K. gentienii [KJ508379]. (K) K. veneficum [KJ508381]. (L) Karlodinium sp. [KJ508385]. (M) Takayama sp. [KJ508387]. (N-P) Kareniaceae sp. (N) [KJ858681]. (O) [KJ508389]. (P) [KJ508390]. Cells fixed with Lugol's solution (A-E, G, L-P). Live cells $(\mathrm{F}, \mathrm{H}-\mathrm{K})$. Scale bars $=10 \mu \mathrm{m}$. 


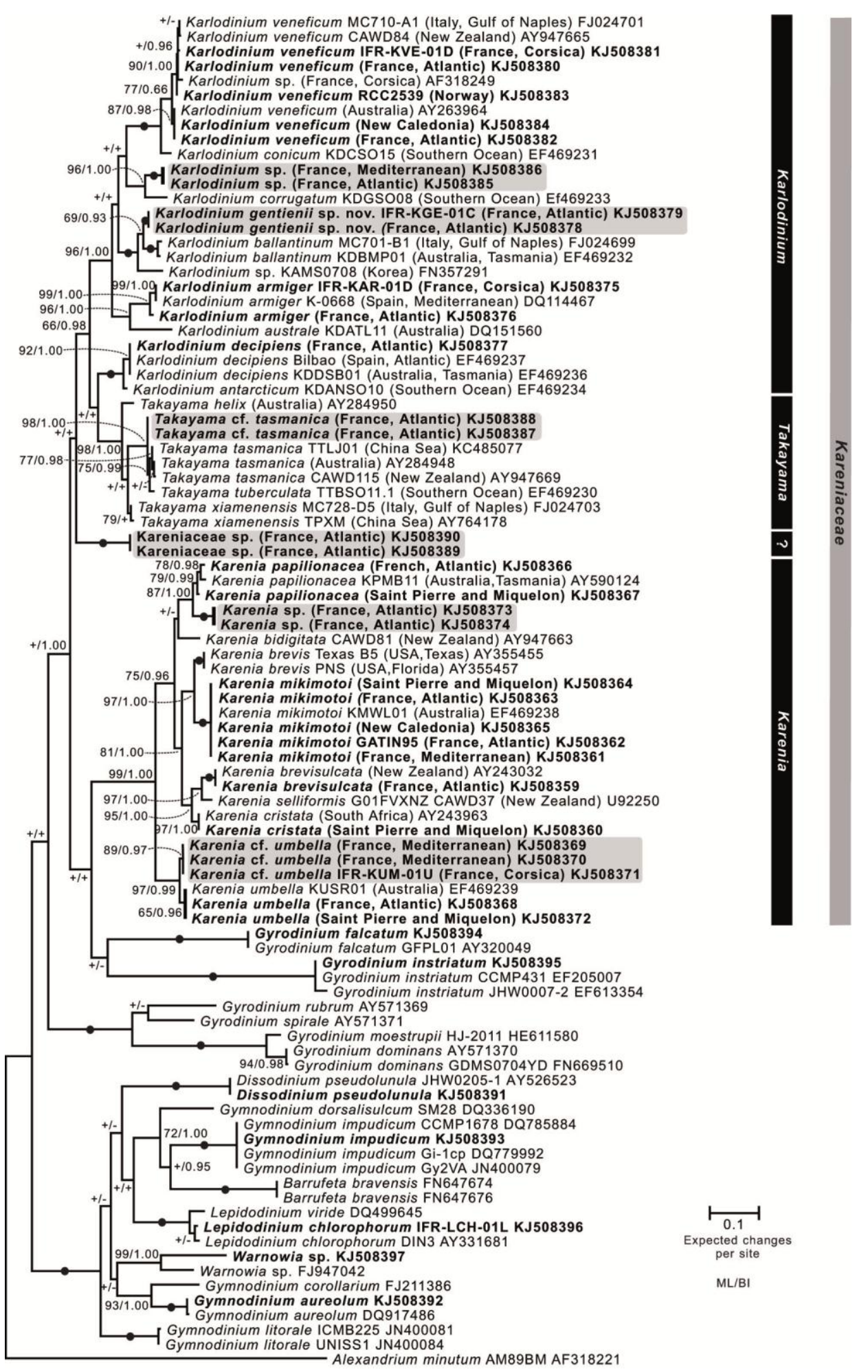

Fig. 2. ML tree of the Kareniaceae (Karenia, Karlodinium, Takayama) inferred from a LSU rDNA (D1-D2 region) data matrix (92 sequences, 830 characters). The tree was rooted using Alexandrium minutum as outgroup. The GeneralTime Reversible model $\left(G T R+\Gamma_{8}\right)$ was chosen in jModeltest. Base frequencies were $f(A)=0.25358 ; f(C)=0.21486 ; f(G)$ $=0.27066$ and $f(T)=0.26091$. Base substitutions rates were $A \leftrightarrow C=0.50398 ; A \leftrightarrow G=1.17068 ; A \leftrightarrow T=0.66736 ; C$ $\leftrightarrow \mathrm{G}=0.79332 ; \mathrm{C} \leftrightarrow \mathrm{T}=3.45783$ against $\mathrm{G} \leftrightarrow \mathrm{T}=1$. Rates at variable sites were assumed to be gamma distributed with the gamma shape parameter estimated to $\alpha=0.4641$. Block dots corresponded to bootstrap values of 100 for Maximum Likehood (ML) and posterior probabilities of 1.00 for Bayesian Inference $(\mathrm{BI})$. Near each node were given bootstrap values of $\mathrm{ML}$ and posterior probabilities of $\mathrm{BI}$ respectively. If bootstrap values were $<65$ and posterior probabilities $<0.85$, the symbol "+" were used. The symbol "-" indicated an irresolution in the bayesian analysis. New sequences acquired in this study are shown in boldface. The taxa that could not be identified at species-level on the sole basis of molecular analysis are overlined in grey. 


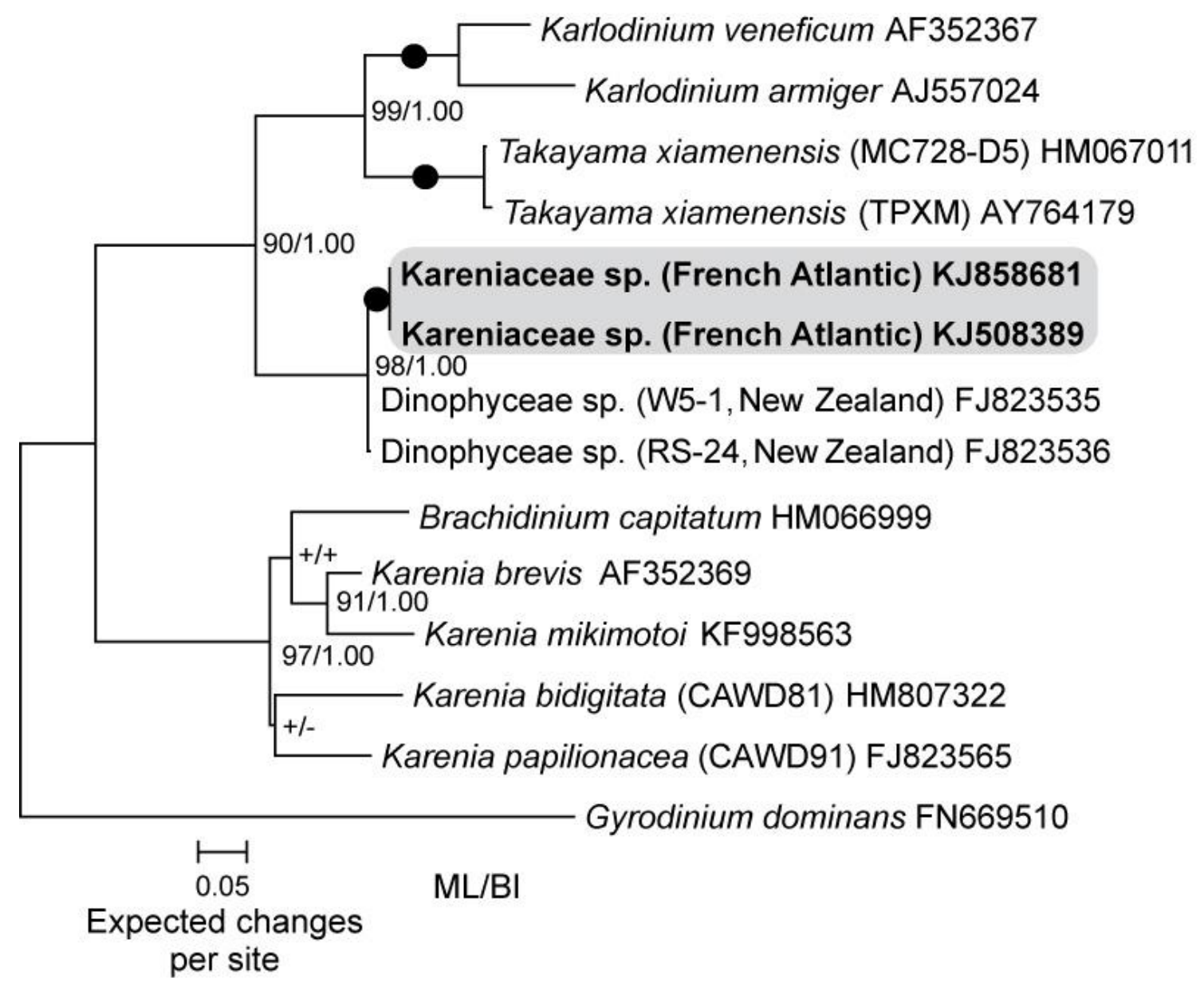

Fig. 3. ML tree of the unidentified kareniacean genus inferred from an ITS region (ITS1, $5.8 S$, and ITS2) data matrix (14 sequences and 784 characters). The tree was rooted using Gyrodinium dominans sequence as outgroup. The General-Time Reversible model $\left(G T R+l_{+} \Gamma_{4}\right)$ was chosen in jModeltest. Base frequencies were $f(A)=0.21769$; $f(C)=0.23280 ; f(G)=0.24615$ and $f(T)=0.30335$. Base substitutions rates were $A \leftrightarrow C$ $=0.49822 ; A \leftrightarrow G=1.27311 ; A \leftrightarrow T=0.97504 ; C \leftrightarrow G=0.45649 ; C \leftrightarrow T=3.65847$ against $\mathrm{G} \leftrightarrow \mathrm{T}=1$. Among-sites rate variation: assumed proportion of invariable sites = 0.214 . Rates at variable sites were assumed to be gamma distributed with the gamma shape parameter estimated to $\alpha=0.467$. Block dots corresponded to bootstrap values of 100 for Maximum Likehood (ML) and posterior probabilities of 1.00 for Bayesian Inference $(\mathrm{BI})$. Near each node were given bootstrap values of $\mathrm{ML}$ and posterior probabilities of $\mathrm{BI}$ respectively. If bootstrap values were $<65$ and posterior probabilities $<0.85$, the symbol "+" were used. The taxon that could not be identified at genus-level on the sole basis of molecular analysis is shown in boldface and overlined in grey. 


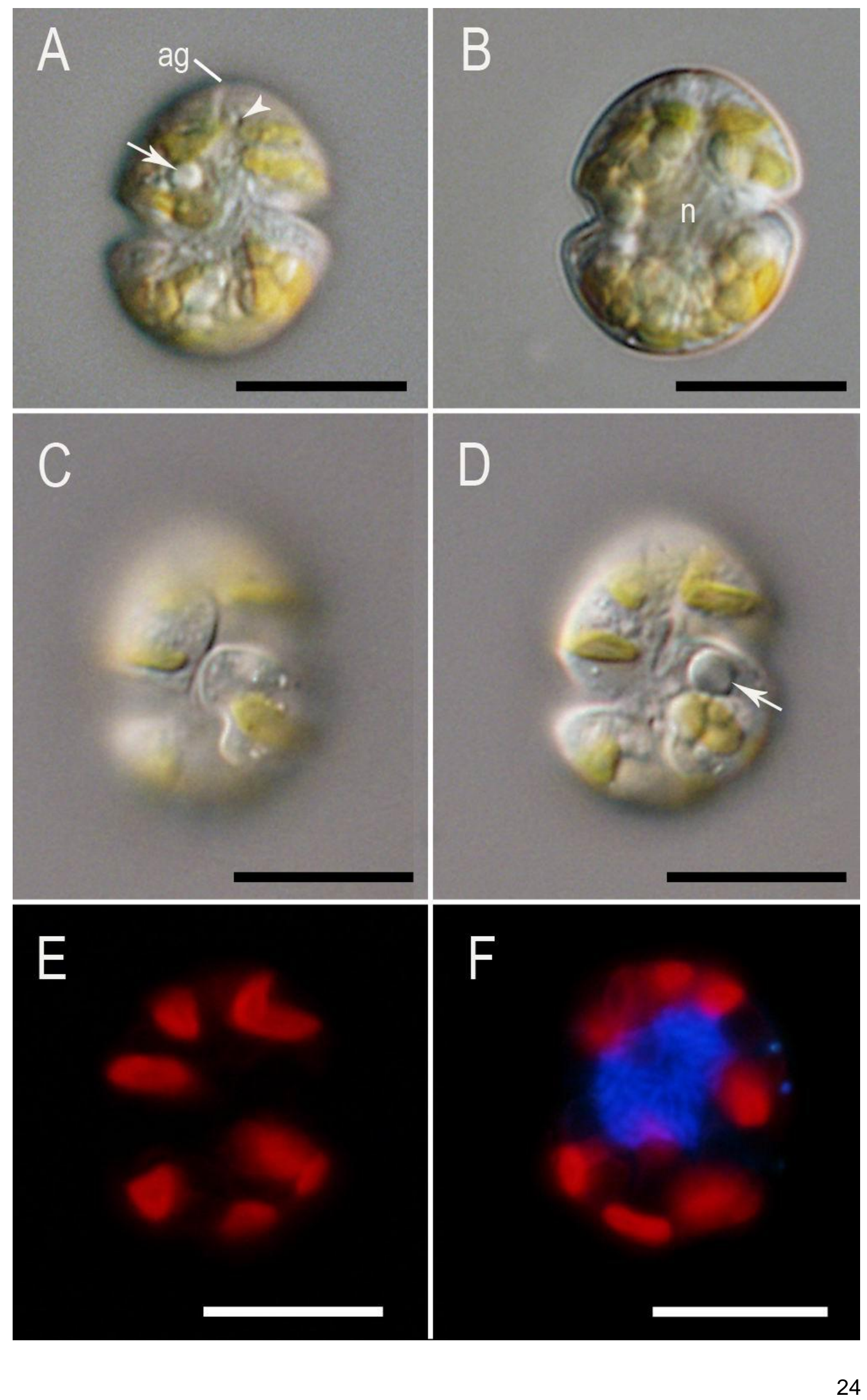


Fig. 4. Light and epifluorescence micrographs of Karlodinium gentienii sp. nov. (strain IFR-KGE-01C). (A) Ventral view of a cell showing the apical groove (ag), the ventral pore (arrowhead), and a refractive body (arrow). (B) Cell in median focus showing the central position of the nucleus (n). (C) Surface focus of cell in ventral view showing the furrows. (D) Ventral view showing the color and the shape of the chloroplasts, and a refractive body (arrow). (E) Cell in epifluorescence microscopy showing the peripheral and irregularly shaped chloroplasts. (F) DAPI-stained cell showing the autofluorescent chloroplasts (red) and the nucleus (blue). Scales bars $=10 \mu \mathrm{m}$. 

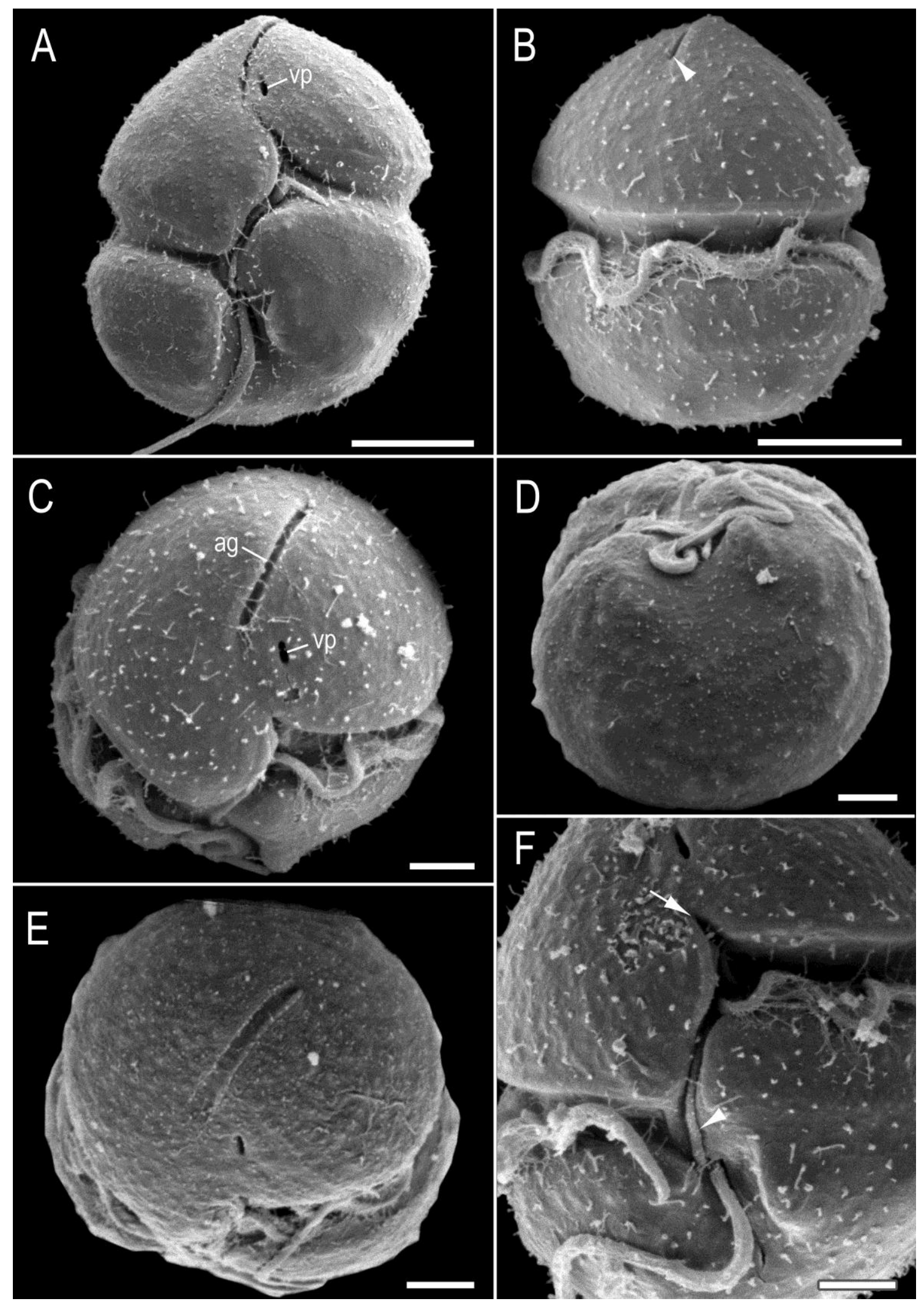

Fig. 5. SEM micrographs of Karlodinium gentienii sp. nov. (strain IFR-KGE-01C). Cells fixed with $2 \%$ $\mathrm{OsO}_{4}$ and $0.5 \%$ glutaraldehyde (final concentrations). (A) Ventral view showing the ventral pore (vp) and the arrangement of furrows. (B) Dorsal view showing the dorsal end of the apical groove (arrowhead). (C) Cell showing the apical groove (ag) and the ventral pore (vp). (D) Antapical view showing a slight dorsoventral compression. (E) Apical view showing the apical groove directed obliquely. (F) Detail of the sulcal region. Note the finger-like protusion on the epicone (arrow) and the peduncle-like in the intercingular region (arrowhead). Scale bars: (A and B) $5 \mu \mathrm{m},(C, D, E$ and F) $2 \mu \mathrm{m}$. 

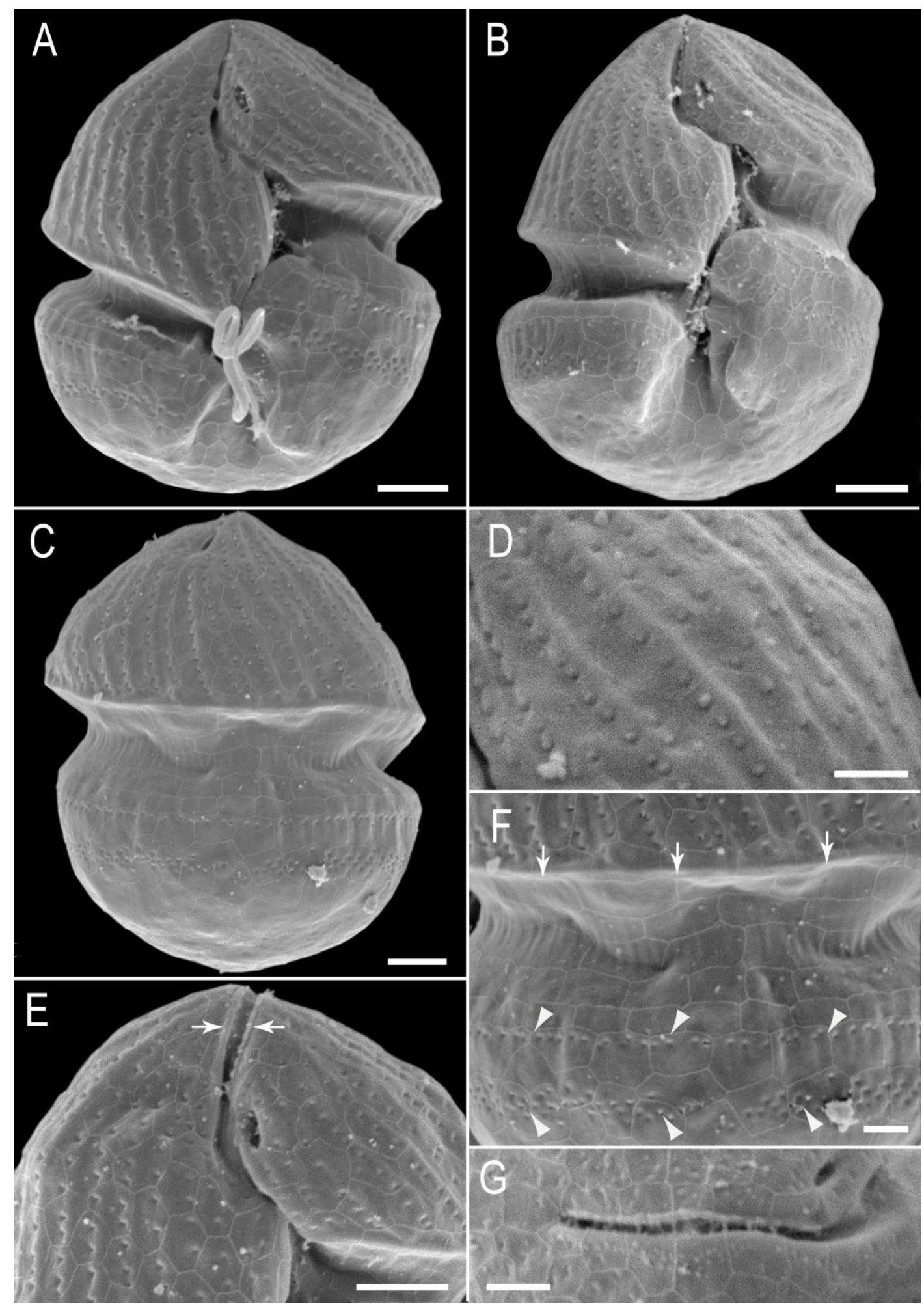

Fig. 6. SEM micrographs of Karlodinium gentienii sp. nov. (strain IFR-KGE-01C). Cells fixed with $1 \%$ acidic Lugol's solution and $1 \%$ glutaraldehyde (final concentrations). (A-B) Ventral views. (A) Parallel spiral furrows on the epicone. (B) Polygonal amphiesmal vesicles covering entirely the cell surface. (C) Dorsal view. (D) Detail of the parallel corrugations and rows of rounded structures on the epicone. (E). Detail of the apical groove with a focus on the thick margins (arrows). (F). Detail of the amphiesmal structure with a focus on the vesicles, the anterior rim of the cingulum (arrows) and the two striae of knobs at cell surface of the hypocone (arrowheads). (G). Apical groove with a focus on the amphiesmal vesicles. Scale bars: (A, B, C and E) $2 \mu \mathrm{m},(D, F$ and $G) 1 \mu \mathrm{m}$. 


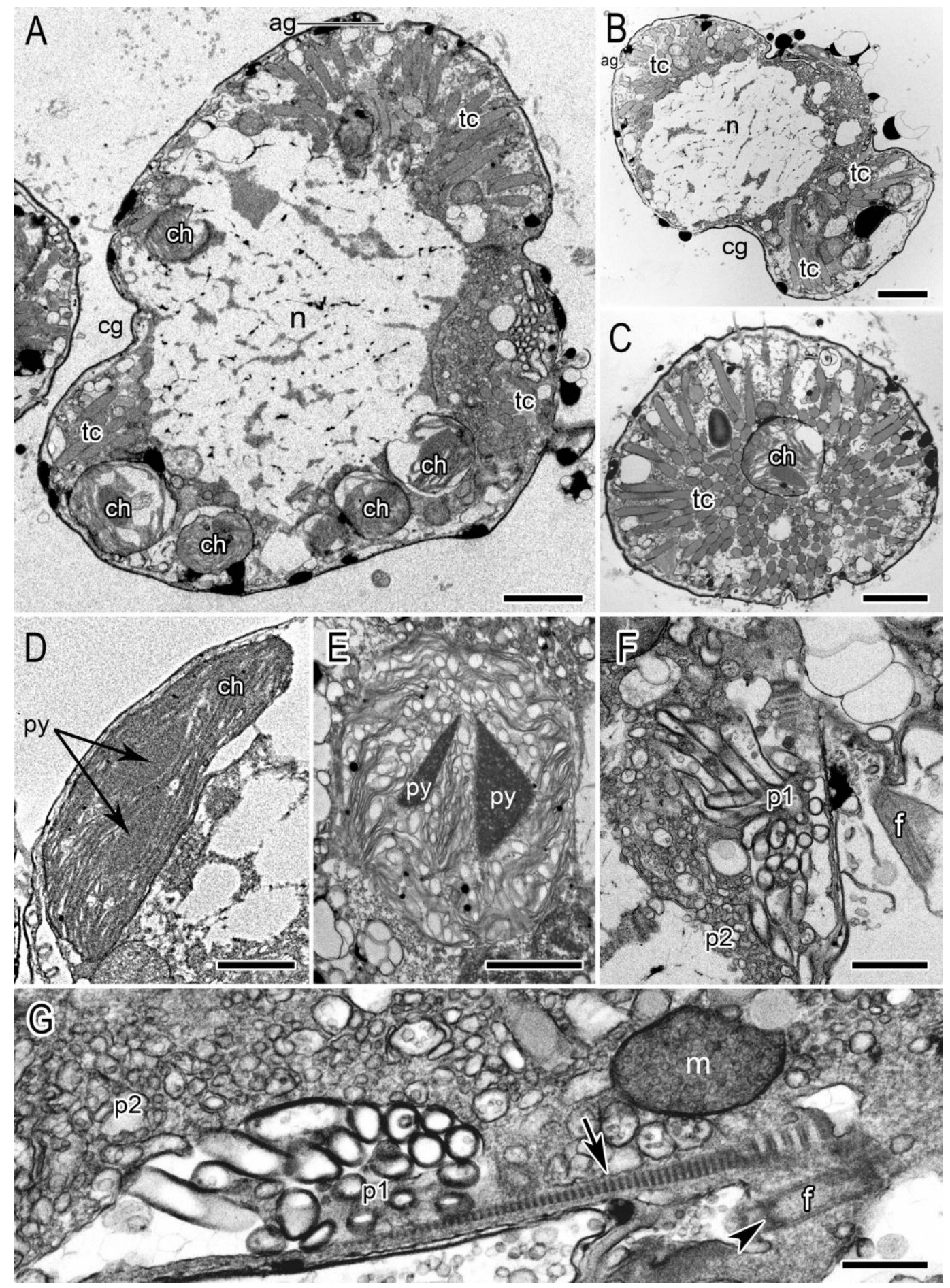

Fig. 7. TEM micrographs of Karlodinium gentienii sp. nov. (strain IFR-KGE-01C). (A-B) Longitudinal sections of a cell in ventral view $(A)$ and in lateral view $(B)$, showing the nucleus $(n)$ and the peripheral chloroplasts (ch). The cingulum (cg) and the apical groove (ag) rims are evident. The array of trichocyst cisternae (tc) are concentrated above the nucleus and below the cingulum. (C) Cross section through a cell above the nucleus, showing the trichocyst cisternae (tc) extending from the inner part of the cell toward the cell membrane. (D-E) Chloroplasts with pyrenoids (py) appearing lenticular in longitudinal section (D) and triangular in cross section (E). (F-G) Sections through the pusule system and the flagellar apparatus. Note that the tubes forming the pusule system ( $\mathrm{p} 1$ and $\mathrm{p} 2$ ) are of two size classes. One flagellum (f), a striated root (arrow), a flagellar base (arrowhead), and a mitochondrion $(\mathrm{m})$ are visible. Scale bars: (A, B and C) $2 \mu \mathrm{m},(\mathrm{D}, \mathrm{E}$ and F) $1 \mu \mathrm{m},(\mathrm{G}) 500 \mathrm{~nm}$. 


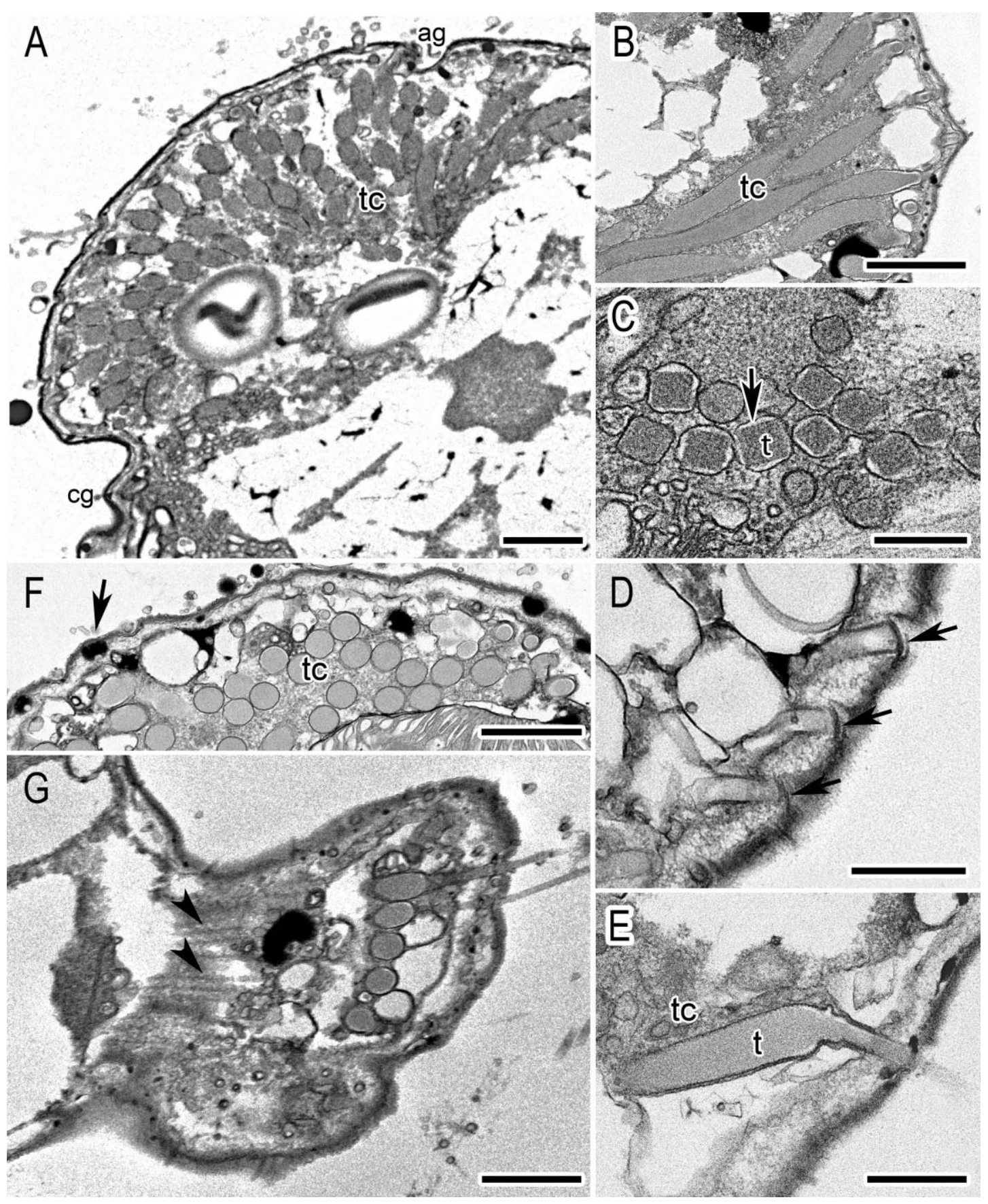

Fig. 8. TEM micrographs of Karlodinium gentienii sp. nov. (strain IFR-KGE). Details of the trichocyst system and the amphiesma. (A-F) Trichocyst cistenae (tc). (A) Array located in the epicone. (B) Cisternae in longitudinal section. (C) Distal part of cisternae in cross section. Note that the trichocysts (t) detach from the cisternae wall (arrow). (D) Lid-like structures covering the trichocyst exits (arrows). (E) A trichocyst during discharge. Note that the lid-like structure is raised. (F) Cross section of cisternae near the amphiesma. Note lipidic droplets within the amphiesma (arrow). (G) Tangential section through the amphiesma. Note the bundles of microtubules (arrowheads). $\mathrm{Ag}=$ apical groove; $\mathrm{cg}=$ cingulum. Scale bars: $\mathrm{A}, \mathrm{B}, \mathrm{F}$ and $\mathrm{G}=1 \mu \mathrm{m}, \mathrm{C}, \mathrm{D}$ and $\mathrm{E}=500 \mathrm{~nm}$. 


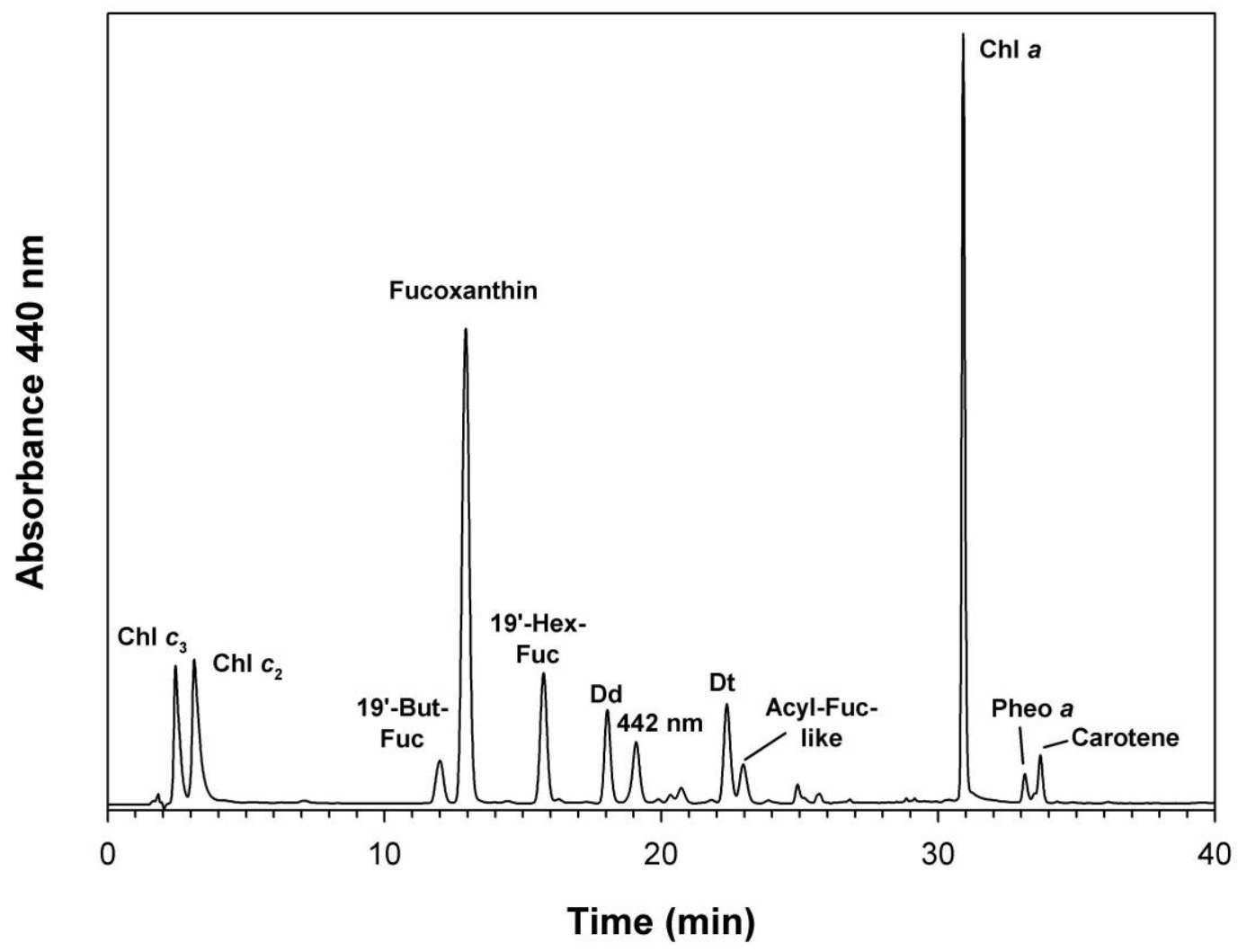

Fig. 9. HPLC chromatogram (absorption at $440 \mathrm{~nm}$ ) of a Karlodinium gentienii culture in exponential growth phase, grown under low light irradiance. Note the absence of nonpolar chl $c$ and gyroxanthin derivatives. 19'-But-Fuc: 19'-Butanoyloxyfucoxanthin; 19'Hex-Fuc: 19'-Hexanoyloxyfucoxanthin; Dd: diadinoxanthin; Dt: diatoxanthin; Acyl-Fuclike: Acyl-fucoxanthin-like compound; Pheo a: pheophytin a. 
Table 2. Estimated ranges of genetic distances (pairwise) between partial LSU rDNA (D1-D2) sequences calculated between individuals (strains) of the same species and between species in the same genus

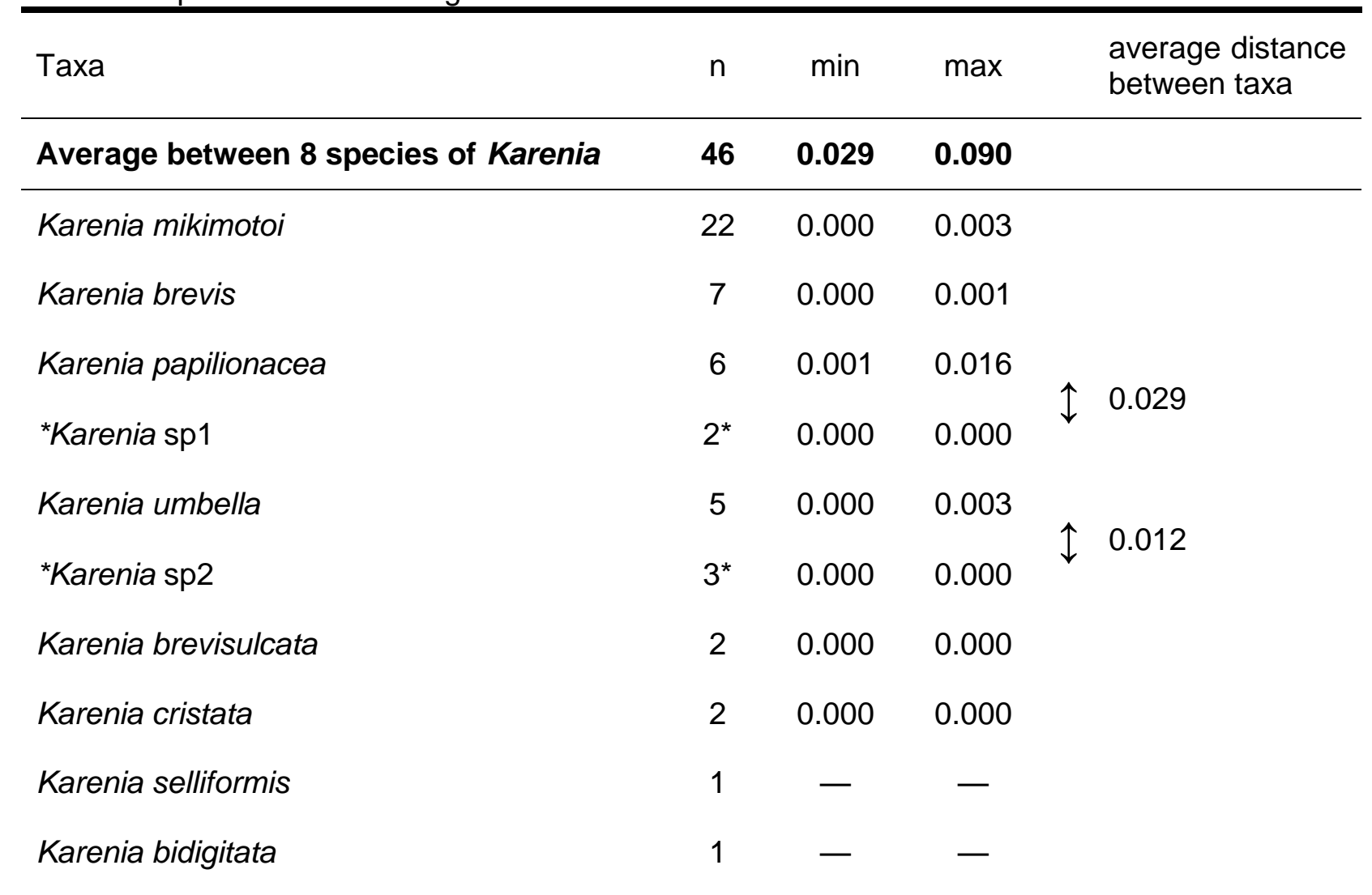

Average between 9 species of Karlodinium (excluding $K$. antarcticum and K. decipiens)

\begin{tabular}{lccccc}
\hline Karlodinium veneficum & 14 & 0.000 & 0.015 & & \\
Karlodinium armiger & 3 & 0.000 & 0.011 & & \\
Karlodinium ballantinum & 3 & 0.000 & 0.007 & & \\
Karlodinium gentienii sp. nov. & 2 & 0.000 & 0.000 & $\uparrow 0.028$ \\
Karlodinium sp. (strain KAMS0708) & 1 & - & - & & \\
Karlodinium australe & 2 & 0.000 & 0.003 & & \\
Karlodinium conicum & 1 & - & - & & \\
Karlodinium corrugatum & 1 & - & - & & \\
*Karlodinium sp. (isolates IFR797/981) & $2^{*}$ & 0.000 & 0.000 & &
\end{tabular}


Average between 5 species of Takayama

$\begin{array}{lll}11 & 0.011 & 0.040\end{array}$

Takayama acrotrocha**

$\begin{array}{lll}4 & 0.018 & 0.032\end{array}$

Takayama xiamenensis

$\begin{array}{lll}3 & 0.000 & 0.000\end{array}$

Takayama helix

Takayama tuberculata

1

- -

Takayama tasmanica

$\begin{array}{lll}3 & 0.000 & 0.000\end{array}$

*Takayama sp.

$2^{*} \quad 0.000 \quad 0.000$

$\uparrow 0.004$

*Sequences of unidentified species acquired in this study were not included in the calculation of average p-distances between species within the same genus.

${ }^{*}$ Sequences of $T$. acrotrocha available in Genbank show a very high level of divergence even in conserved parts of the alignment. 
Table 3: Morphological characters of Karlodinium gentienii, in comparison with other Karlodinium species.

\begin{tabular}{|c|c|c|c|c|c|c|c|c|c|c|}
\hline & $\begin{array}{l}\text { Karlodinium } \\
\text { gentienii }\end{array}$ & $\begin{array}{l}\text { Karlodinium } \\
\text { corsicum }^{a}\end{array}$ & $\begin{array}{l}\text { Karlodinium } \\
\text { veneficum }^{b} \\
(\mathrm{~K}-0522)\end{array}$ & $\begin{array}{l}\text { Karlodinium } \\
\text { armiger }^{b}\end{array}$ & $\begin{array}{l}\text { Karlodinium } \\
\text { australe }^{c}\end{array}$ & $\begin{array}{l}\text { Karlodinium } \\
\text { antarcticum }^{d}\end{array}$ & $\begin{array}{l}\text { Karlodinium } \\
\text { ballantinum } \\
e\end{array}$ & $\begin{array}{l}\text { Karlodiniu } \\
\text { m conicum }\end{array}$ & $\begin{array}{l}\text { Karlodinium } \\
\text { corrugatum }^{d}\end{array}$ & $\begin{array}{l}\text { Karlodiniu } \\
m \\
\text { decipiens }^{d}\end{array}$ \\
\hline $\begin{array}{l}\text { Cell } \\
(\mu \mathrm{m})\end{array}$ & $\begin{array}{l}13.5-18.9 \\
(16.3 \pm 1.5 \\
n=30)\end{array}$ & $17-24$ & $\begin{array}{l}8-18(13.6 \pm \\
1.9, n=50)\end{array}$ & $\begin{array}{l}12-22 \quad(17.4 \\
\pm 2.4, n=50)\end{array}$ & $\begin{array}{l}19-26 \quad(21.8 \\
\pm 1.8, n=30)\end{array}$ & $\begin{array}{l}15-24 \quad(19.2 \\
\pm 0.2, n=76)\end{array}$ & $\begin{array}{l}11-18 \quad(14.6 \\
\pm 0.2, n=73)\end{array}$ & $\begin{array}{l}19-29 \\
(24.3 \pm 0.2 \\
n=80)\end{array}$ & $\begin{array}{l}13-21 \quad(16.2 \\
\pm 0.1, n=100)\end{array}$ & \multirow{4}{*}{$\begin{array}{l}18-25 \\
(21.4 \pm 0.2 \\
n=50) \\
13-19 \\
(16.2 \pm 0.2 \\
n=50) \\
1.15-1.55 \\
(1.32 \quad \pm \\
0.01, n=50) \\
33\end{array}$} \\
\hline Cell width $(\mu \mathrm{m})$ & $\begin{array}{l}11.5-16.8 \\
(13.6 \pm 1.4 \\
n=30)\end{array}$ & $12-16$ & $\begin{array}{l}8-14(11.1 \pm \\
1.4, n=50)\end{array}$ & $\begin{array}{l}8-18(13.1 \pm \\
1.8, n=50)\end{array}$ & $\begin{array}{l}16-22 \quad(18.9 \\
\pm 1.8, n=30)\end{array}$ & $\begin{array}{l}10-14 \quad(12.0 \\
\pm 0.1, n=76)\end{array}$ & $\begin{array}{l}8-14(10.9 \pm \\
0.2, n=73)\end{array}$ & $\begin{array}{l}15-25 \\
(19.9 \pm 0.2 \\
n=80)\end{array}$ & $\begin{array}{l}11-17 \quad(13.9 \\
\pm 0.1, n=100)\end{array}$ & \\
\hline $\begin{array}{l}\text { Length to width } \\
\text { ratio }\end{array}$ & $\begin{array}{l}1.11-1.33 \\
(1.20 \pm \quad 0.05 \\
n=30)\end{array}$ & $1.21^{\dagger}$ & $\begin{array}{l}0.97-1.49 \\
(1.23 \pm 0.1 \\
n=50)\end{array}$ & $\begin{array}{l}1.15-1.55 \\
(1.33 \pm 0.1 \\
n=50)\end{array}$ & $1.14^{\dagger}$ & $\begin{array}{l}1.36-2.12 \\
(1.60 \pm 0.01 \\
n=76)\end{array}$ & $\begin{array}{l}1.20-1.58 \\
(1.35 \pm 0.01 \\
n=73)\end{array}$ & $\begin{array}{l}1.05-1.39 \\
(1.22 \quad \pm \\
0.01, n=80)\end{array}$ & $\begin{array}{l}0.99-1.36 \\
(1.17 \pm 0.01 \\
n=100)\end{array}$ & \\
\hline $\begin{array}{l}\text { Girdle } \\
\text { displacement } \\
\text { (\% cell length) }\end{array}$ & $25-31$ & $32-34$ & $23-32$ & $29-36$ & 25 & $20-33$ & 33 & 25 & 25 & \\
\hline \multirow{3}{*}{$\begin{array}{l}\text { Sulcal } \\
\text { extension } \\
\text { Apical groove }\end{array}$} & Yes & Yes & Yes & Yes & Yes & \multirow{3}{*}{$\begin{array}{l}\text { Inconspicuou } \\
\text { s or absent } \\
\text { Very long, } \\
\text { extending } \\
\text { halfway down } \\
\text { the dorsal } \\
\text { epicone }\end{array}$} & $\begin{array}{l}\text { Short } \\
\text { evident }\end{array}$ & Yes & Yes & \multirow{3}{*}{$\begin{array}{l}\text { Inconspicu } \\
\text { ous fold } \\
\text { Long, } \\
\text { extending } \\
\text { halfway } \\
\text { down the } \\
\text { dorsal } \\
\text { epicone }\end{array}$} \\
\hline & $\begin{array}{l}\text { Linear, } \\
\text { descending } \\
\text { one-sixth }\end{array}$ & $\begin{array}{l}\text { With a curved } \\
\text { base, } \\
\text { descending }\end{array}$ & $\begin{array}{l}\text { Straight, } \\
\text { descending } \\
\text { one-seventh }\end{array}$ & $\begin{array}{l}\text { Straight, } \\
\text { descending } \\
\text { one-fourth }\end{array}$ & $\begin{array}{l}\text { Short and } \\
\text { straight, } \\
\text { extending }\end{array}$ & & $\begin{array}{l}\text { Very short } \\
\text { and linear, } \\
\text { extending }\end{array}$ & $\begin{array}{l}\text { Relatively } \\
\text { short, } \\
\text { extending }\end{array}$ & $\begin{array}{l}\text { Medium } \\
\text { sized, } \\
\text { extending }\end{array}$ & \\
\hline & $\begin{array}{l}\text { down the } \\
\text { dorsal } \\
\text { epicone }\end{array}$ & $\begin{array}{l}\text { one-third } \\
\text { down the } \\
\text { dorsal } \\
\text { epicone }\end{array}$ & $\begin{array}{l}\text { down the } \\
\text { dorsal } \\
\text { epicone }\end{array}$ & $\begin{array}{l}\text { down the } \\
\text { dorsal } \\
\text { epicone }\end{array}$ & $\begin{array}{l}\text { only briefly } \\
\text { onto the } \\
\text { dorsal } \\
\text { epicone }\end{array}$ & & $\begin{array}{ll}\text { very briefly } \\
\text { onto the } \\
\text { dorsal } \\
\text { epicone }\end{array}$ & $\begin{array}{l}\text { one-fourth } \\
\text { down the } \\
\text { dorsal } \\
\text { epicone }\end{array}$ & $\begin{array}{l}\text { approximatel } \\
\text { y one-third } \\
\text { down the } \\
\text { dorsal } \\
\text { epicone }\end{array}$ & \\
\hline Ventral pore & $\begin{array}{l}\text { Elongated } \\
(0.8-1.0 \mu \mathrm{m}) \text {, } \\
\text { above the } \\
\text { sulcal } \\
\text { intrusion, } \\
\text { next to the } \\
\text { base of the } \\
\text { carina }\end{array}$ & $\begin{array}{l}\text { Kidney- } \\
\text { shaped, next } \\
\text { to the curved } \\
\text { base of the } \\
\text { apical groove }\end{array}$ & $\begin{array}{l}\text { Elongated } \\
(1 \mu \mathrm{m}) \text { to the } \\
\text { left of the } \\
\text { apical groove }\end{array}$ & $\begin{array}{l}\text { Elongated } \\
(1 \mu \mathrm{m}) \text { to the } \\
\text { left of the } \\
\text { apical groove }\end{array}$ & $\begin{array}{l}\text { Reniform, } \\
\text { above and to } \\
\text { the left of the } \\
\text { sulcal } \\
\text { intrusion }\end{array}$ & $\begin{array}{l}\text { Inconspicuou } \\
\text { s or absent }\end{array}$ & $\begin{array}{l}\text { Absent or } \\
\text { inconspicuou } \\
\text { s }\end{array}$ & $\begin{array}{l}\text { Conspicuo } \\
\text { us and } \\
\text { round, } \\
\text { halfway } \\
\text { between } \\
\text { the sulcal } \\
\text { termination } \\
\text { and the }\end{array}$ & $\begin{array}{l}\text { Slit-like, } \\
\text { located far to } \\
\text { the left of the } \\
\text { sulcal region } \\
\text { and the } \\
\text { carina }\end{array}$ & $\begin{array}{l}\text { Slit-like, } \\
\text { located } \\
\text { above the } \\
\text { sulcus }\end{array}$ \\
\hline
\end{tabular}


Amphiesma structure
Polygonal

vesicles,

numerous

rows

micro-

structures on micro-

the epicone structures

and only 2 irregularly

rows below arranged on

the cingulum, the epicone

numerous and two

trichocysts parallel rows

dischargeabl on

e in the hypocone

epicone and

below the

cingulum, no

evidence of

plugs beginning

of the carina

Two striae of n.a.

n.a.

knobs, one

on the

epicone and

the other one

on the

\section{rows, every rounded parallel}

depression structures microtubular

comprising a randomly bands, no

plug

evidence of

placed

hypocone 
Table S1. List of sequences used for p-distances calculations (on D1-D2 region) in table 2.

\begin{tabular}{|c|c|c|c|}
\hline species & strain/isolate & origin & $\begin{array}{l}\text { Genbank } \\
\text { accession } \\
\text { number }\end{array}$ \\
\hline \multirow[t]{22}{*}{ Karenia mikimotoi } & AC213 & - & HM807332 \\
\hline & CCMP430 & - & HM807333 \\
\hline & CCMP429/PLY497a & - & AF200678 \\
\hline & $\mathrm{K}-0286$ & Australia & AF200679 \\
\hline & KMWL01 & Australia & EF469238 \\
\hline & K-0579 & Denmark & AF200682 \\
\hline & GATIN95 & France, Atlantic & KJ508362 \\
\hline & IFR559 & France, Atlantic & KJ508363 \\
\hline & IFR980 & France, Mediterranean & KJ508361 \\
\hline & $?$ & Japan & AF200681 \\
\hline & MBA561 & Japan & HM807325 \\
\hline & GMKUSJAP CAWD05 & Japan & U92247 \\
\hline & IFR11-056 & New Caledonia & KJ508365 \\
\hline & CAWD117 & New Zealand & HM807326 \\
\hline & CAWD133 & New Zealand & HM807327 \\
\hline & CAWD134 & New Zealand & HM807328 \\
\hline & G01WAINZ, IS02 & New Zealand & U92249 \\
\hline & KT77B & & AF200680 \\
\hline & K-0260 & Norway & HM807331 \\
\hline & IFR13-379 & Saint-Pierre-and-Miquelon & KJ508364 \\
\hline & CCMP429 & United Kingdom & HM807329 \\
\hline & NOAA-2 & USA, Florida & AY355460 \\
\hline \multirow[t]{7}{*}{ Karenia brevis } & Jacksonville C3-5 & - & DQ847431 \\
\hline & GRHIUS CAWD08 & New Zealand & U92248 \\
\hline & JL32 & USA, Florida & AF200677 \\
\hline & PNS & USA, Florida & AY355457 \\
\hline & JaxC5 & USA, Florida & AY355459 \\
\hline & Texas B5 & USA, Texas & AY355455 \\
\hline & sp3 & USA, Texas & AY355456 \\
\hline \multirow[t]{6}{*}{ Karenia papilionacea } & KPMB11 & Australia, Tasmania & AY590124 \\
\hline & IFR562 & France, Atlantic & KJ508366 \\
\hline & KAGAWA-15 & Japan & AB771743 \\
\hline & G01HAWNZ, IS16 & New Zealand & U92252 \\
\hline & VGO679 & Spain & FN649411 \\
\hline & IFR13-294 & St-Pierre-and-Miquelon & KJ508367 \\
\hline \multirow[t]{2}{*}{ Karenia sp1 } & IFR572 & France, Atlantic & KJ508374 \\
\hline & IFR528 & France, Atlantic & KJ508373 \\
\hline \multirow[t]{5}{*}{ Karenia umbella } & KUSR01 & Australia & EF469239 \\
\hline & KUTN05 & Australia, Tasmania & AY263963 \\
\hline & KULV01 & Australia, Tasmania & AY263962 \\
\hline & IFR644 & France, Atlantic & KJ508368 \\
\hline & IFR13-377 & Saint-Pierre-and-Miquelon & KJ508372 \\
\hline Karenia sp2 & $\begin{array}{l}\text { IFR868 } \\
\text { IFR1186 }\end{array}$ & $\begin{array}{l}\text { France, Mediterranean } \\
\text { France, Mediterranean }\end{array}$ & $\begin{array}{l}\text { KJ508369 } \\
\text { KJ508370 }\end{array}$ \\
\hline
\end{tabular}




\begin{tabular}{|c|c|c|c|}
\hline Karenia brevisulcata & $\begin{array}{l}\text { IFR-KUM-01U } \\
\text { IFR1133 }\end{array}$ & $\begin{array}{l}\text { France, Corsica } \\
\text { France, Atlantic } \\
\text { New Zealand }\end{array}$ & $\begin{array}{l}\text { KJ508371 } \\
\text { KJ508359 } \\
\text { AY243032 }\end{array}$ \\
\hline Karenia cristata & IFR13-067 & $\begin{array}{l}\text { Saint-Pierre-and-Miquelon } \\
\text { South Africa }\end{array}$ & $\begin{array}{l}\text { KJ508360 } \\
\text { AY243963 }\end{array}$ \\
\hline Karenia selliformis & CAWD37 & New Zealand & U92250 \\
\hline Karenia bidigitata & CAWD81 & New Zealand & AY947663 \\
\hline Karlodinium veneficum & $\begin{array}{l}\text { KDMPT01 } \\
\text { IFR10-150 } \\
\text { IFR10-101 } \\
\text { IFR-KVE-01D } \\
\text { MC710-A1 } \\
\text { IFR11-130 } \\
\text { CAWD84 } \\
\text { G01WHKNZ IS03 } \\
\text { K-0522 } \\
\text { RCC2539 } \\
\text { BgT1 } \\
\text { Plymouth-103 } \\
\text { Pim05JulC4 }\end{array}$ & $\begin{array}{l}\text { Australia } \\
\text { France, Atlantic } \\
\text { France, Atlantic } \\
\text { France, Corsica } \\
\text { France, Corsica } \\
\text { Italy } \\
\text { New Caledonia } \\
\text { New Zealand } \\
\text { New Zealand } \\
\text { Norway } \\
\text { Norway } \\
\text { Tunisia } \\
\text { United Kingdom } \\
\text { USA, Florida }\end{array}$ & $\begin{array}{l}\text { AY263964 } \\
\text { KJ508380 } \\
\text { KJ508382 } \\
\text { AF318249 } \\
\text { KJ508381 } \\
\text { FJ024701 } \\
\text { KJ508384 } \\
\text { AY947665 } \\
\text { U92257 } \\
\text { AF200675 } \\
\text { KJ508383 } \\
\text { DQ898222 } \\
\text { DQ114466 } \\
\text { AY245692 }\end{array}$ \\
\hline Karlodinium armiger & $\begin{array}{l}\text { K-0668 } \\
\text { IFR10-093 } \\
\text { IFR-KAR-01D }\end{array}$ & $\begin{array}{l}\text { France, Atlantic } \\
\text { France, Corsica }\end{array}$ & $\begin{array}{l}\text { DQ114467 } \\
\text { KJ508376 } \\
\text { KJ508375 }\end{array}$ \\
\hline Karlodinium ballantinum & $\begin{array}{l}\text { KDBMP01 } \\
\text { MC701-B1 } \\
\text { MC728-A1 }\end{array}$ & $\begin{array}{l}\text { Australia, Tasmania } \\
\text { Italy } \\
\text { Italy }\end{array}$ & $\begin{array}{l}\text { EF469232 } \\
\text { FJ024699 } \\
\text { FJ024700 }\end{array}$ \\
\hline Karlodinium gentienii & $\begin{array}{l}\text { IFR-KGE-01C } \\
\text { IFR10-074 }\end{array}$ & $\begin{array}{l}\text { France, Atlantic } \\
\text { France, Atlantic }\end{array}$ & $\begin{array}{l}\text { KJ508379 } \\
\text { KJ508378 }\end{array}$ \\
\hline Karlodinium sp. & KAMS0708 & Korea & FN357291 \\
\hline Karlodinium australe & $\begin{array}{l}\text { KDATL11 } \\
\text { GT5 }\end{array}$ & $\begin{array}{l}\text { Australia } \\
\text { Singapore }\end{array}$ & $\begin{array}{l}\text { DQ151560 } \\
\text { DQ156228 }\end{array}$ \\
\hline Karlodinium conicum & KDCSO15 & Australia & EF469231 \\
\hline Karlodinium corrugatum & KDGSO08 & Australia & EF469233 \\
\hline Karlodinium sp. & $\begin{array}{l}\text { IFR797 } \\
\text { IFR981 }\end{array}$ & $\begin{array}{l}\text { France, Atlantic } \\
\text { France, Mediterranean }\end{array}$ & $\begin{array}{l}\text { KJ508385 } \\
\text { KJ508386 }\end{array}$ \\
\hline Takayama acrotrocha & $\begin{array}{l}\text { CCMP2960 } \\
\text { clone GT17 } \\
\text { clone GT15 }\end{array}$ & $\begin{array}{l}\text { Singapore } \\
\text { Singapore } \\
\text { Singapore }\end{array}$ & $\begin{array}{l}\text { HQ834208 } \\
\text { DQ656117 } \\
\text { DQ656116 }\end{array}$ \\
\hline
\end{tabular}




\begin{tabular}{llll} 
& clone GT7 & Singapore & DQ656115 \\
Takayama xiamenensis & GSXM03 & China & KC485078 \\
& MC728-D5 & Italy & FJ024703 \\
MC728-B4 & Italy & FJ024702 \\
Takayama helix & TTNWB01 & Australia & AY284950 \\
Takayama tuberculata & TTBSO11.1 & Australia & EF469230 \\
Takayama tasmanica & TTTL02 & Australia & AY284949 \\
& TTDE01 & Australia, Tasmania & AY284948 \\
& TTLJ01 & China & KC485077 \\
Takayama sp. & IFR863 & France, Atlantic & KJ508387 \\
& IFR909 & France, Atlantic & KJ508388 \\
\hline
\end{tabular}


Table S2. Presence/absence of gyroxanthin and non polar-chl $\mathrm{C}_{2}$ derivatives among 35 Karlodinium strains of 5 species. The symbol + indicates the presence of the pigment, the symbol - indicates the absence. Gyro: gyroxanthin.

\begin{tabular}{|c|c|c|c|c|}
\hline Species & Strain & $\begin{array}{c}\text { Gyro } \\
\text { derivatives }\end{array}$ & $\begin{array}{l}\text { Non polar- } \\
\quad{\text { chl } c_{2}}\end{array}$ & Reference \\
\hline K. armiger & GC-2 & + & + & Garcés et al. (2006) \\
\hline K. armiger & GC-3 & + & + & Garcés et al. (2006) \\
\hline K. armiger & GC-7 & + & + & Garcés et al. (2006); Zapata et al. (2012) \\
\hline K. armiger & K-0668 & + & $?$ & Bergholtz et al. (2006) \\
\hline K. australe & KDAGT03 & - & + & De Salas et al. (2005) \\
\hline K. australe & KDATL05 & - & + & De Salas et al. (2005) \\
\hline K. australe & KDAPP01 & - & + & De Salas et al. (2005) \\
\hline K. decipiens & Nervion34 & + & + & Zapata et al. (2012) \\
\hline K. gentienii & IFR-KGE-01C & - & - & This study \\
\hline K. veneficum & RCC2539 & + & - & This study \\
\hline K. veneficum & CCMP1974 & + & - & $\begin{array}{l}\text { Kempton et al. (2002); Zapata et al. } \\
(2012)\end{array}$ \\
\hline K. veneficum & CCMP1975 & + & - & Bachvaroff et al. (2009) \\
\hline K. veneficum & CCMP2388 & + & - & Bachvaroff et al. (2009 \\
\hline K. veneficum & CCMP2282 & + & - & Bachvaroff et al. (2009) \\
\hline K. veneficum & CCMP2283 & + & - & Bachvaroff et al. (2009) \\
\hline K. veneficum & CCMP2064 & + & - & Bachvaroff et al. (2009) \\
\hline K. veneficum & 010410-C6 & + & - & Kempton et al. (2002) \\
\hline K. veneficum & CCMP415 & + & - & Zapata et al. (2012) \\
\hline K. veneficum & CCMP2778 & + & - & Bachvaroff et al. (2009) \\
\hline K. veneficum & CS-310 & + & - & Zapata et al. (2012) \\
\hline
\end{tabular}




\begin{tabular}{|c|c|c|c|c|}
\hline K. veneficum & GC-1 & + & - & Garcés et al. (2006) \\
\hline K. veneficum & GC-4 & + & - & Garcés et al. (2006); Zapata et al. (2012) \\
\hline K. veneficum & GC-5 & + & - & Garcés et al. (2006) \\
\hline K. veneficum & VG0691 & + & - & Zapata et al. (2012) \\
\hline K. veneficum & VGO870 & + & - & Zapata et al. (2012) \\
\hline K. veneficum & MD2 & + & - & Bachvaroff et al. (2009) \\
\hline K. veneficum & MD5 & + & - & Bachvaroff et al. (2009 \\
\hline K. veneficum & MD6 & + & - & Bachvaroff et al. (2009 \\
\hline K. veneficum & Slocum & + & - & Bachvaroff et al. (2009) \\
\hline K. veneficum & MBM1 & + & - & Bachvaroff et al. (2009) \\
\hline K. veneficum & IB4 & + & - & Bachvaroff et al. (2009) \\
\hline K. veneficum & PD-6 & + & - & Bachvaroff et al. (2009) \\
\hline K. veneficum & $\mathrm{F} 4$ & + & - & Bachvaroff et al. (2009) \\
\hline K. veneficum & CAWD66 & + & - & Bachvaroff et al. (2009) \\
\hline K. veneficum & CAWD83 & + & - & Bachvaroff et al. (2009) \\
\hline
\end{tabular}

